\title{
Microplastics and Wastewater Treatment Plants-A Review
}

\author{
Rana Zeeshan Habib'1, Thies Thiemann², Ruwaya Al Kendi ${ }^{*}$ \\ ${ }^{1}$ Department of Biology, College of Science, United Arab Emirates University, Al Ain, UAE \\ ${ }^{2}$ Department of Chemistry, College of Science, United Arab Emirates University, Al Ain, UAE \\ Email: ${ }^{\star}$ ruwayaa@uaeu.ac.ae
}

How to cite this paper: Habib, R.Z., Thiemann, T. and Al Kendi, R. (2020) Microplastics and Wastewater Treatment Plants-A Review. Journal of Water Resource and Protection, 12, 1-35. https://doi.org/10.4236/jwarp.2020.121001

Received: November 27, 2019

Accepted: January 3, 2020

Published: January 6, 2020

Copyright (c) 2020 by author(s) and Scientific Research Publishing Inc. This work is licensed under the Creative Commons Attribution International License (CC BY 4.0).

http://creativecommons.org/licenses/by/4.0/

(c) (i) Open Access

\begin{abstract}
The emission of microplastics into nature poses a threat to aquatic and terrestrial ecosystems. Their penetration of the food chain presents a danger to human health as well. Wastewater treatment plants can be seen as the last barrier between microplastics and the environment. This review focuses on the impact of waste treatment plants in retaining microplastics. Studies show that no wastewater treatment method leads to a complete retention of microplastics, and so wastewater treatment plants themselves are viewed as point sources for the discharge of microplastics into the aquatic environment. Problems associated with the utilization of microplastic loaded sewage sludge are also discussed in the review.
\end{abstract}

\section{Keywords}

Microplastics, Waste Water Treatment, Sewage Sludge, Aquatic Environment

\section{Introduction}

Synthetic plastics have existed for just over a century [1], with their mass production starting in the 1950s [2]. In 2015 alone, 322 million metric tons of plastic were produced worldwide as compared to 350 thousand metric tons in 1950 [3]. Some of the plastic is recycled or incinerated for energy recovery at its end-of-life, where the fraction of the recycled plastic depends on the region. Thus, in 2009, 13.1 million out of 45 million metric tons of end-of-life plastic were either recycled (5.5 million tons) or incinerated ( 7.6 million tons) in the EC countries. There remains a significant difference in recycling efforts in different countries of the European community, however, with Germany leading in plastic recycling with slightly over $60 \%$ of end-of-life plastic being recycled and slightly less than $40 \%$ incinerated in 2011 [4]. Nevertheless, that leaves a signifi- 
cant amount of plastic material ending up as non-recycled waste. The inherent characteristics of polymer-derived plastics such as their high durability, light weight and inexpensiveness, which makes them so attractive for numerous applications and contribute to their dominance in the marketplace, make them environmental pollutants threatening biodiversity in both aquatic and terrestrial ecosystems. Already in the 1960s [5], there were spurious reports of birds ingesting plastic litter [6]. In the early 1970s, two important papers on the occurrence of plastic pellets in the Western Sargasso Sea [7] and of polystyrene pellets in coastal waters off UK [8] helped put the focus on the effect of plastic derived pollutants on marine ecosystems, and waste plastic debris came to be considered as a new global environmental challenge [9] [10]. Today, it is estimated that about 5 trillion plastic particles are floating on the oceans, weighing 250,000 metric tons [11]. Overall, it is thought that with 275 million metric tons generated in 2010 (up from 245 million tons in 2008), 4.8 to 12.7 million metric tons of plastic debris entered the oceans that year alone [12]. Similarly, lakes and rivers exhibit a high load of plastic contamination that may range from 5 to 10 pieces/L [13] [14] [15]. The major sources of marine plastics include beach littering, cargo shipping, discharges from wastewater treatment plants, and harbor and fishery operations [16] [17] [18] [19].

In the last decade, a new threat associated with plastic materials was identified: microplastics. In academia, contributions on "microplastics and the environment" started to appear in 2006, and grew rapidly in number from 2009 onwards, resulting in 500 scientific articles for 2018, alone (Figure 1). Microplastics are defined as plastic particles of $\leq 5 \mathrm{~mm}$ in size [9] [20] [21]. More recently, the term nanoplastic has been coined for particles $\leq 1 \mu \mathrm{m}$ in size [9] [22], although some authors define nanoplastics as particles of up to $100 \mathrm{~nm}$ in size [23], with the discussion still ongoing [24]. Nanoplastics in the environment are more difficult to detect and quantify adequately and will pose a challenge for years to come. Microplastics can be divided into "primary" and "secondary". "Primary" microplastics acquire their size during production. "Primary" microplastics can be

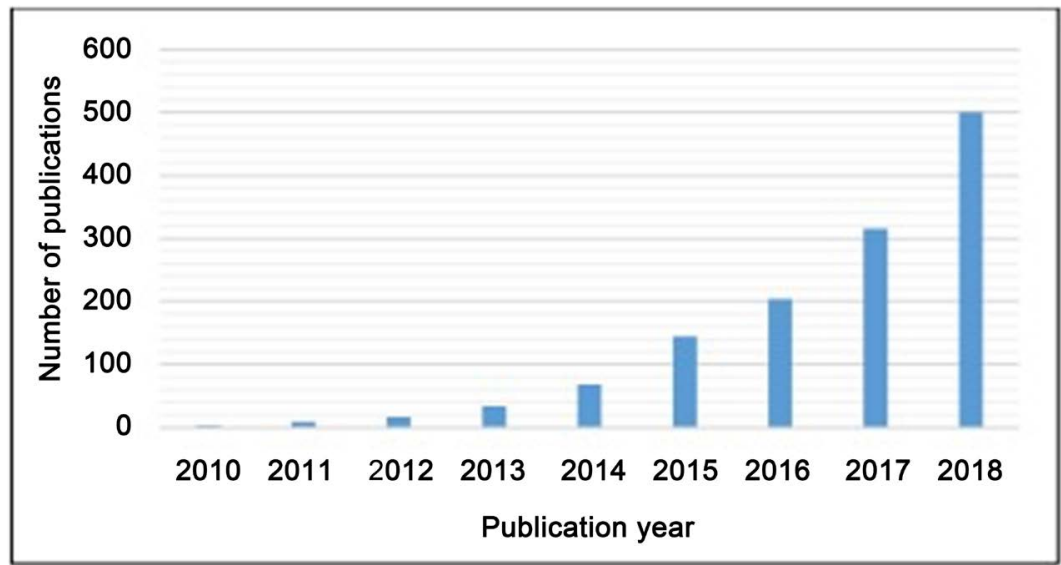

Figure 1. Publications found with the keywords "microplastics" AND "environment" using the database Web of Science (Clarivate Analyticals ${ }^{\circledR}$ ). 
found as micropellets in cosmetic formulations and in facial cleaners and body scrubs (median size of $0.2-0.4 \mathrm{~mm}$ ), as microspherules in toothpastes $(2-5 \mu \mathrm{m}$ in size), as well as in scrubbers used for air-blasting surfaces to remove paints and rust [25] and as drilling fluids in oil and gas exploration. A newer application is their use in drug delivery systems [26] [27]. In addition, synthetic polymer containing microparticles can also be released by the degradation of materials. The release of microfibers as a result of the washing of textiles has been widely reported as a source of microplastics [28] [29] [30] [31] [32]. These synthetic fibers, released by washing machines, are transported to waste water treatment plants [29] [33], where a considerable amount of them pass through the different treatment stages into the effluents due to their smaller size and enter the aquatic environment. It is estimated that around 35\% of microplastics reaching the ocean are from synthetic textiles [34].

Inventories of microplastics entering the environment have been attempted by organizations in different countries. A breakdown of the sources of microplastics in Sweden has been provided by Magnusson [35], which is given in detail below as an example of typical microplastic streams in developed countries. There is microplastic emission from plastic production, sandblasting material, cosmetic products, pharmaceutical drugs, textiles, road material and coatings. Using a spill factor of $0.04 \%$, which was also used by Sundt et al. [26] for the estimation of pellet loss from the Norwegian plastic production plants, K. Magnusson et al. [35] have calculated a direct micropellet emission of 298 tons per year. In addition to that, there is loss due to the handling of plastic pellets which is set at between $0.0005 \%$ and $0.01 \%$, adding another $12-235$ tons of microplastics emitted into the environment. These numbers were modeled on emission factors proposed by Lassen et al. [36] for the Danish production industry. However, no actual measured numbers of emissions of microplastics during production exist. The use of microplastics (e.g. of urea formaldehyde resins) in abrasive products for sandblasting has been deemed to be limited, and the use of these materials in Swedish shipyards is strictly regulated. As to plastic particle containing drugs and vaccines, most of the polymers used for this purpose are assumed to be biodegradable, however, polycarbonate and polystyrene materials have been known to be used, also [37]. There is very little information what half-life they have in the human or animal body and how they are excreted, although a number of studies do exist on the uptake of micro- and nanoparticles, including of microplastics in mammals [38] and of nano-sized drug delivery systems in humans [39] [40]. No study has been done on their environmental impact [35]. As a complete overview of personal care products in Sweden was not possible, the report based its numbers on microplastics in liquid soap. Here, it was found that in 2012 Europe used 4360 tons of microplastics in liquid soap [41], of which 60 tons were used in Sweden [35]. To these might be added synthetic fibers, which contribute a large share to microplastics in our environment. It has been found that the laundering of $6 \mathrm{~kg}$ of synthetic textiles can release up to 729,000 fibers in 
one wash, with a new $100 \%$ polyester fleece shirt losing $0.4 \mathrm{w} \%$ of its weight at the first wash (for discharge rates of synthetic fibers from washing textiles), see [28] [42] [43] [44]. From this data, Magnusson et al. [35] have calculated an emission of 8 - 945 tons of synthetic fibers from Swedish households into the wastewater. Incidentally, household dust can act as a reservoir of synthetic fibers and other microplastics, contributing on the average $0.5 \mathrm{w} \%-1.5 \mathrm{w} \%$ to the dust [45]. This leads to an estimate of 1 - 19 tons of microplastics in household dust in Sweden [35]. To this is added 93 tons per year of emissions from protective coatings and 35 - 158 tons per year from decorative coatings [35], 1638 - 2456 tons of potential loss of granulates from sports grounds and facilities with similar turfs [35]. Emissions due to road wear and abrasion of tires will be discussed, below. A similar compilation of primary sources of microplastics has been published by the countries Norway [26] Denmark [36] and Germany [30].

"Secondary" microplastics originate from larger plastic pieces that have deteriorated and broken down over time through weathering or other "wear-and-tear". Microplastics in the environment can stem from the fragmentation of larger size materials that have already been emitted to the environment. The degradation of plastics can be influenced by the action of photodegradation, as well as by chemical, physical and biological action [46] [47] [48].

In principle, all of these microplastic materials can be transported to the ocean by rivers, discharged by water treatment plants or through surface-run off, often aided by the wind [49]. Wastewater treatment plants are of great importance to retain hazardous waste material that otherwise would be discharged unhindered into the environment [50]. Therefore, the current article looks at recent studies of the retention of microplastics in wastewater treatment plants.

\section{Composition of Microplastics, Their Distribution in the Environment and Their Impact on Living Organisms}

Microplastics include a diversity of polymers that can be divided into seven main basic types: polyvinyl chlorides (PC, 1), polyethenes (low density [LDPE], high density [HDPE], 2), polyamides (PA, 3), polypropylenes ( $\mathrm{PP}, 4)$, polyurethanes (PU, 5), polystyrenes (PS, 6) and polyethylene terephthalates (7) [51] [52] [53] (Figure 2). Nevertheless, the European community has listed more than 130 different polymers as constituents of microplastics [54] [55]. The share of the different materials in the overall worldwide production of plastics is given by PlasticsEurope as follows: PP $(4,23 \%$, for packaging, food containers and textiles), PE (2, 17\% LDPE, 15\% HDPE, for plastic bags, packaging, microbeads), PS (6, 7\%, for packaging), PET (7, 7\%, for plastic bottles, synthetic fibers), and PA (3, 1\%, fibers [nylon]). In addition, there are poly(methyl)methacrylates (8, PPMA, $1 \%$, for synthetic glass) and polycarbonates $(9,1 \%$, for plastic bottles and synthetic glass) [56].

Plastic particles, many of them microplastics, have been detected in ocean surface waters with an average density of as high as $3.3 \times 10^{5}$ plastic fragments $/ \mathrm{km}^{2}$ 
<smiles>[Z]C(C)CC(C)(CC)C(C)(C)C</smiles>

1<smiles>[Z][C@H](C)CCC(C)(C)CSC</smiles>

2<smiles>CC(C)(C)NC(=O)C(C)(C)C</smiles>

3<smiles>[Z]C(C)CC(C)C(C)(C)CC</smiles>

4

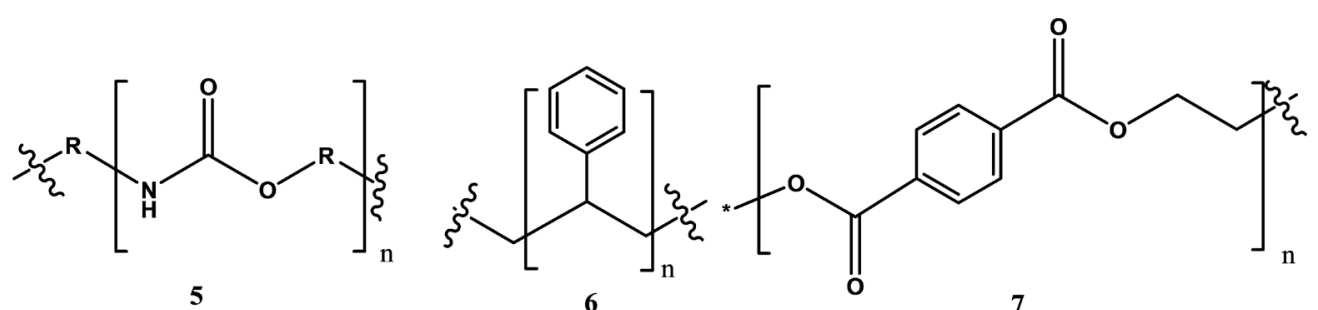

7<smiles>CCC(C)(C)C(C)(C)C(=O)OC</smiles>

8<smiles>[Z6]C(=O)Oc1ccc(C(C)(C)c2ccc(OC)cc2)cc1</smiles>

9

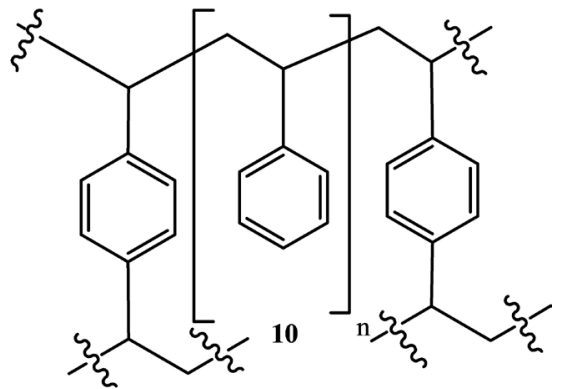

Figure 2. Chemical structures of the most important polymer types found in microplastics.

(in the North Pacific gyre) [25] and of 8 - 124 fibers per L sediment on beaches [28] [57] with fresh water bodies having a concentration of $0.55 \times 10^{5}$ to $342 \times$ $10^{5}$ items $/ \mathrm{km}^{2}$ [58] [59]. Even in Arctic waters, just south and southwest of Svalbard, Norway, microplastics have been found, at a mean concentration of $0.34 \pm$ 0.32 particles per $\mathrm{m}^{3}$ on the water surface [60]. Although microplastics can be found in the surface water, there are denser microplastics that can be found at different depths in the water column and that finally can be embedded in sediments [33] [61]. In fact, it has been estimated that about two-thirds of the microplastics end up on the ocean floor in sediments and one-sixth on sea-shores. Terrestrial ecosystems have been found with a mean concentration of $5 \mathrm{mg} \mathrm{mi-}$ croplastic/kg soil [62]. The pervasive presence of microplastics in nature means that all forms of organisms are exposed to microplastics [16]. Intricate studies have looked at the impact of microplastics on different organisms, both in their natural habitat and in laboratory settings. There is some trepidation about the impact of microplastics on biodiversity, which has been expressed in recent papers [63] [64] [65]. Thus, it has been shown that larger invertebrate species ingest microplastics, mistaking them for their natural prey because of similarities in shape, size and color, e.g., mistaking them for plankton [66]-[73]. There is some worry that microplastics accumulate along the food chain [74] [75] [76] with the accumulation of microplastics in the digestive tract of Talitrus saltator (Crustacea, Amphipoda), a species which is heavily fed upon by birds, given as an example [77]. Lastly, there is also the worry that ultimately microplastics can 
reach humans [78] [79], although there is no proof thus far of accidental ingestion of microplastics through marine food sources [80]. That there can be an effect of microplastics on organisms has been demonstrated without doubt [81]. First reports date from the late 1980s and early 1990s with Hart's studies on the feeding rates of the purple sea urchin Strongylocentrotus purpuratus upon ingestion of polystyrene divinylbenzene (10) microspheres [82]. Later studies have revealed that microplastic ingestion can lead to growth inhibition [83] [84] [85], reproductive disorders [84] [86], reduced viability [87] and in extreme cases, increased mortality [88] [89] of microalgae, lugworms, marine bivalves and amphipods, respectively. In 2012, the secretariat of the Convention on Biological Diversity (CBD) reported that man-made marine litter has known negative impacts on 663 species studied [90]. While meso- and macroplastics often affect larger organisms directly, microplastics in the marine environment affect crustaceans, mussels, fish and plankton directly [30].

A complicating factor is that microplastics can carry pathogens [91], chemical pollutants and potentially invasive species [92]. Organic matter can easily adsorb on the surface of microplastics. The hydrophobicity and large surface area of the microplastics usually facilitate the adsorption. Studied organic pollutants that attach themselves to microplastics and that are of high toxicity are DDTs (e.g., 11) [93], hexachlorocyclohexanes (12) [94], chlorinated benzenes (13) [95], chlorinated biphenyls (14) [96], and polycyclic aromatic hydrocarbons (PAHs) such as pyrene (15) [97], fluoranthene (16) [98] and benzo[a]pyrenes (17) [99] (Figure 3). In addition, organic materials that are inherent to the microplastics<smiles>Clc1ccc(C(c2ccc(Cl)cc2)C(Cl)(Cl)Cl)cc1</smiles>

11<smiles>ClC1C(Cl)C(Cl)C(Cl)C(Cl)C1Cl</smiles>

12<smiles>CC1(c2ccccc2)CCCC1</smiles>

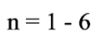<smiles>Clc1cccc(-c2cccc(Cl)c2)c1</smiles>

14<smiles></smiles>

15

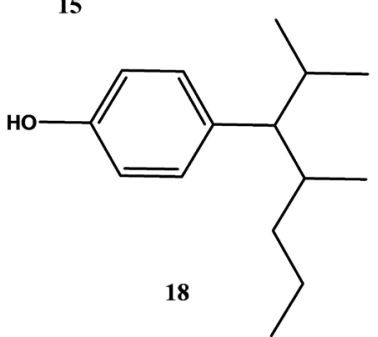

13<smiles>c1ccc2c(c1)-c1cccc3cccc-2c13</smiles>

17
16<smiles>c1ccc2c(c1)cc1ccc3cccc4ccc2c1c34</smiles><smiles>CC(C)(c1ccc(O)cc1)c1ccc(O)cc1</smiles>

19

Figure 3. Typical organic pollutants and polymer constituents (e.g., 19) that can be transported by microplastics. 
themselves and that stem from the production process, such as nonylphenol (18) and bisphenol A (19), have been found to leach from the microplastics into the environment [100]. These include flame retardants such as tris-(2-chloroethyl) phosphate (TCEP, 20) and tris-(1-chloro-2-propyl) phosphate (TCPP, 21) as well as the ubiquitous plasticizer di(-2-ethylhexyl) phthalate (DEHP, 22) [57]. Clearly, for microplastics originating from the breakdown of larger plastic pieces, other common flame retardants must be considered such as the many brominated flame retardants, decabromodiphenyl ether (23), tetrabromobisphenol A (24) and tetrabromobisphenol A-bis(2,3-dibromopropyl ether) (25), among others [101] (Figure 4). These organic compounds can be released into the tissue of living organisms. A plethora of studies have been performed to understand the desorption of the organic material from the microplastic and its transport into the organisms' tissues [102]. In addition, it has been found that also heavy metals such as cadmium, lead, zinc, and nickel can be transported by microplastics [103] [104].

\section{Wastewater Treatment Plants and Microplastics}

A major share of the microplastics entering the environment does so through sewage water. This includes micropellets stemming from cosmetic formulations, especially from facial scrubs [105], and textile fibers [106], the latter coming from the shedding of particles during the washing process of textiles [28] [107] [108]. It has been noted that textile fibers released to the environment for the most part are natural fibers. Talvitie et al. have reported that the most common fibers emitted from a large wastewater treatment plant (WWTP) in Finland were natural (66\%), where (natural) cotton and (synthetic) polyester made the largest contribution with $44 \%$ and $33 \%$, respectively [109]. As organic pollutants in general are adsorbed on fibers, regardless of whether they are natural or synthetic, and textile fibers tend to be impregnated with flame retardants, both

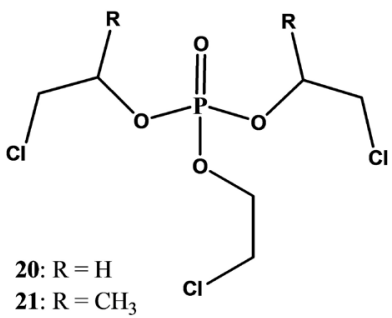<smiles>CCCCCCCC(C)COC(=O)c1ccccc1C(=O)OCC(C)C</smiles><smiles>Brc1ccc(Cc2ccc(Br)cc2)cc1</smiles>

23<smiles>CC(C)(c1cc(Br)c(O)c(Br)c1)c1cc(Br)c(OCC(Br)CBr)c(Br)c1</smiles>

Figure 4. Flame retardants and plasticizers that can be constituents of microplastics. 
could lead to an environmental impact. However, natural fibers tend to degrade more quickly.

Even though the abundance of microplastics and their impact on the environment have been studied extensively, especially in the last decade, the idea that wastewater treatment plants can also be considered as point sources in the release of microplastics into the aquatic environment has only recently gained traction, both within the scientific community [29] [109]-[119] and within governmental agencies [26] [120]. Vermaire et al. have found a significantly higher concentration of microplastics downstream of a wastewater treatment plant (1.99 per $\left.\mathrm{m}^{3}\right)$ on the Ottawa river as compared to upstream $\left(0.71\right.$ per $\left.\mathrm{m}^{3}\right)$ [119]. Other studies have found an elevated concentration of microplastics (MPs) downriver from WWTPs [14] [121] [122] [123]. Municipal and industrial effluent runoffs contain macro- and microplastics. While large plastics tend to be removed in water processing units, technologies in WWTPs are not specifically designed to remove or degrade the micro- or nanoplastics from final effluents [110] [114] [124]. Thus, effluents containing microplastics enter the oceans from municipal sewage treatment plants directly or indirectly via riverine systems [25] [28] [33]. It is estimated that in Europe alone, effluents from wastewater treatment plants are releasing 520,000 tons of plastic every year [15]. It must be noted, however, that microplastics smaller than $5 \mu \mathrm{m}$ are not easily quantified (see below) and not always recorded, and therefore the numbers could in fact be higher. The abundant presence of polypropylene (4) and polyethylene (2) beads and acrylic (26), polyamide (3), polyester (27) and nylon (28) fibers in marine sediments reflect this [14] [25] [28] [29] [117] [124] [125] [126] [127] [128] (Figure 5). A comparison of plastic fibers detected in shoreline sediment with samples and fibers collected from wastewater effluents clearly suggests that a considerable portion of detected microfibers is associated with wastewater effluents [28]. Microplastics found in the Laurentian Great Lakes with an abundance $7.4 \times 10^{5}$ particles $/ \mathrm{km}^{2}$ were linked to wastewater treatment plant effluents [125] as were microplastics found in St. Lawrence River sediments [129]. Then,

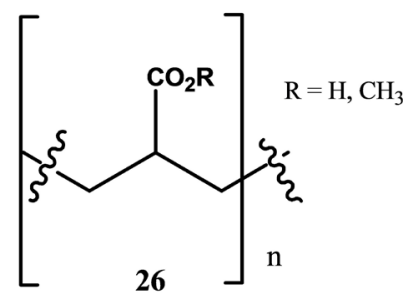

26

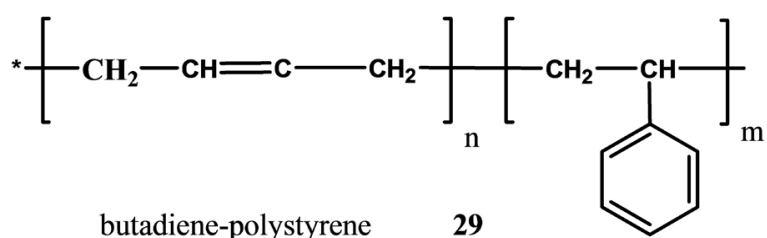<smiles>[R]NC(=O)OC(=O)CC</smiles>

28<smiles>CC(=CCC(C)(C)C)CC(C)(C)C</smiles>

natural rubber (polyisoprene)
30

Figure 5. Chemical structures of polymers in microplastics, also in tire and road wear particles (TRWP). 
there is the issue with microplastics stemming from personal care products. A statistical analysis revealed that worldwide wastewater treatment plants are passing 8 trillion microbeads into our aquatic ecosystems daily [130]. Microplastics from personal care products can take the form of spherical beads, but oftentimes have irregular shapes, so that they are not always well identified when present in an environmental sample. Oftentimes, the particles characterized as "fragments" in the individual studies on microplastics in the environment have the size and topography of microplastics found in personal care-product formulations [105] [131]. Therefore, many studies view particles described as "fragments" and (spherical) micropellets as microbeads. This may lead to uncertainties in the quantification of plastic microbeads from personal care products as reported from different regions of the globe.

Tire and road wear material can be seen as synthetic plastic containing and have been the focus of a number of studies. Of late, the contribution of tire and road wear particles (TRWP) to microplastic emissions has been highlighted, where within the area of the Seine watershed per capita release of TRWP was estimated to be $1.8 \mathrm{~kg} /$ year, with $2 \%$ of that amount being transported to the Seine estuary [132] [133]. In the same paper, the author estimated a TRWP generation rate of $1 \mathrm{~kg}$ per inhabitant and year throughout Europe [132]. It has been estimated that 2300 tons of TRWP have been transported into the Mediterranean Sea and 1600 tons into the Black Sea, both in the year 2000 alone [134]. However, different numbers come from Sweden, where an annual emission of 7674 tons of rubber wear [35] and 110,000 tons of asphalt abrasion is calculated [35] [135], of which about 23,000 tons is extremely mobile material [136] [137], making for $3 \mathrm{~kg}$ mobile TRWP generation per inhabitant and year. This would amount to $0.76 \mathrm{~kg} /$ inhabitant and year of tire wear alone. Similar data has been obtained in Norway (4500 t/year [26]) and Denmark (4200 - 6600 t/year [36]), while for Germany, the numbers estimated left a large margin of uncertainty (60 - 110,000 t/year [30]). Tires contain styrene-butadiene rubber (29) and natural rubber (30) (Figure 5), two materials that as anthropogenic macromolecular compounds have started to be included in the term "plastics" [132] [138]. The study by Unice et al. [132] set the wastewater treatment plant's removal efficiency of TRWP at $95 \%$.

Municipal wastewater treatment facilities have a basic common design (Figure 6), although each facility will differ in the configuration of this basic design. Aeration, flocculation, and sedimentation can be seen as the common steps of the process. The primary treatment removes large debris items with screen meshes sized $6 \mathrm{~mm}$ or larger. It has been understood that an average of $65 \%$ of the influent microplastics are removed during a typical primary treatment stage [139], where microplastics of low density tend to collect in the grease layer [117], where they are skimmed off [111]. Secondary treatment removes suspended and dissolved organic material, through the action of microorganisms within large aeration tanks. By flocculation processes and in settling tanks sewage sludge is 


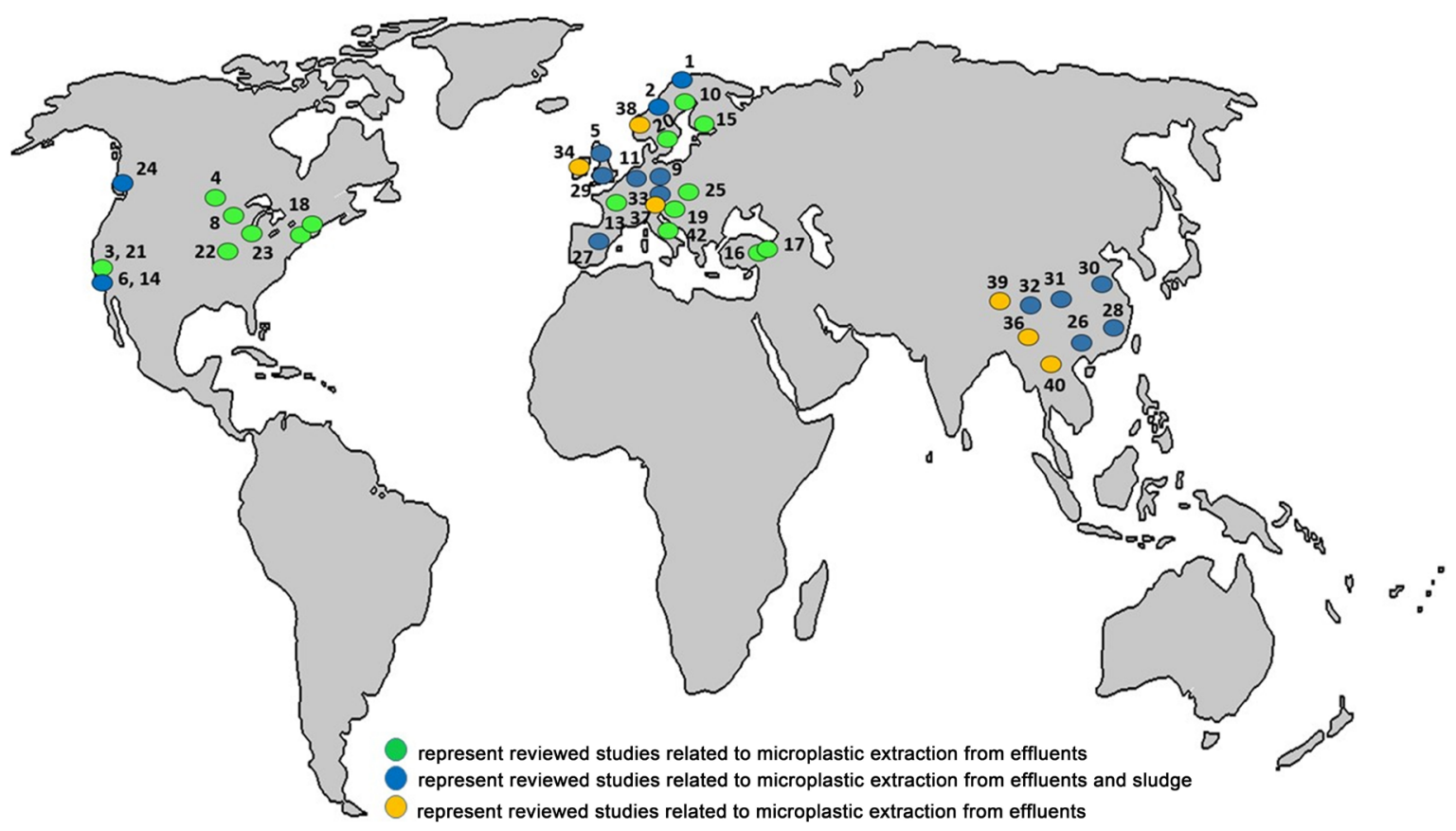

Figure 6. Site map of the studies reviewed in this article.

separated from the post-processing effluent. This is followed by disinfection processes, polishing or possibly advanced (tertiary) treatment, such as filtration through sand and/or activated carbon columns, before the treated water is discharged into a neighboring waterbody. Removal rates of $96 \%$ - $99 \%$ for secondary wastewater treatment plants [112] [115] [117] and of $90 \%-99.9 \%$ for tertiary wastewater treatment plants [111] [115] [118] [140] have been reported. Nevertheless, it has been noted that even the tertiary stage proves ineffective to completely remove the microplastic from the final effluent [109] [141], see also below. Thus, as microplastic is not specifically targeted in any of the three treatment phases, it can escape through the treatment plants [142] and via effluents finally reaches the ocean [28]. Nevertheless, it has also been noted that beads/pellets, although thoroughly studied (see below), are by far the least abundant constituent of microplastics in the effluents of the wastewater treatment plants [139], with fibers making up the major contribution to the microplastics being released by wastewater treatment plants [28] [114]. This can be seen nicely in the work of R. Sutton et al. [141], where $80 \%$ of microplastics found in the effluent of four WWTPs with secondary and four WWPTs with tertiary treatment on San Francisco bay have been noted to be fibers. Similar results have been reported by Vermaire et al., where $70 \%$ and more of the plastic particles in the effluent have been found to be microfibers [119].

Situations have been found to be quite different for different water treatment plants, depending on the composition of the influx and the type of wastewater treatment plant. The outcomes of the studies also depend on the sampling and analysis techniques, i.e., to what minimum size the microplastics were quantified. Primpke et al. found that microplastic emissions can be quite different on two 
different days, so that sampling time and duration of the study are important variables in assessing the retention of microplastics in different wastewater treatment plants [161]. Evidently, all water treatment plants reduce the number of microplastics, when comparing influx to effluent (see Table 1). Many investigations have concentrated on plastic microbeads [117] [147], which mostly derive from daily care products such as facial cleansers, body washes, including shampoos, and toothpastes. Early studies have found relatively low concentrations of microplastics in the treated water ranging from 0.0009 [111] to 0.009 particles per L [55] for secondary treatment and 0.00002 [111] to 1 particle per L [28] for tertiary treatment. A study of the effluent from 8 WTTPs in the San Francisco bay area found no microbeads at all in the 0.086 microplastic particles per $\mathrm{L}$ discharge [141], although plastic fragments made up $17 \%$ of the discharged microplastics. A study of a large secondary wastewater treatment plant on the River Clyde, Glasgow, serving approx. 650,000 inhabitants, was found to reduce the number of microbeads from $15.7( \pm 5.23)$ particles per $\mathrm{L}$ to $0.25( \pm 0.24)$ particles per L [117]. This constitutes a reduction of $98.4 \%$, which is comparable to the results of a Swedish study involving a small water treatment facility serving 14,000 people [55], where $99 \%$ of the microbeads were retained by the water treatment plant. Nevertheless, it was calculated that the water treatment plant on the Clyde still discharges $6.5 \times 10^{7}$ microbeads into the river per day. This number may be compared with the estimated 8 trillion $\left(8 \times 10^{12}\right)$ microbeads which are released into the aquatic environment worldwide on a daily basis [65]. For Lubljana, Slovenia, G. Kalč́ková et al. have estimated a release of $15.2 \mathrm{mg}$ of microbeads per person into the sewerage water with $1.1 \times 10^{8}$ particles reaching the river water giving a microbead concentration of 21 particles $/ \mathrm{m}^{3}$. Furthermore, lab experimentation showed that on average $52 \%$ of microbeads were captured by activated sludge, constituting a large fraction of the smaller particles (60 - 70 $\mu \mathrm{m})$, while the larger particles were less well retained [147]. Studies from mainland China estimate that up to 209.7 trillion microbeads (equaling 306.9 tons) are carried into the aquatic environment annually, 167.5 trillion microbeads of which stem from an incomplete removal in wastewater treatment plants [162], with the remainder originating from untreated wastewater, mostly from urban areas. A US estimate for the release of microbeads through treated sewage into American waterways for 2015 is conservative at 2.9 trillion beads [163]. A more recent estimate based on a newer assessment of the wastewater volume being processed [164] puts this number at 1.1 trillion - 8.4 trillion microbeads per year [114]. A study performed in New York State in 2015 found that of 34 water treatment facilities in the state, microbeads were found in the treated effluent of 25 treatment plants [120]. Of the 9 facilities, where no microbeads could be confirmed, 6 employed advanced filtration techniques such as membrane microfiltration, continuous backwash upflow dual sand (CBUDS) microfiltration and rapid sand filters [120]. However, 4 of the facilities, where microbeads had been found in the treated effluent, also used filtration techniques such as rapid sand 
Table 1. Displays the large variety in the concentration of microplastics that has been reported in waste water effluents (Browne et al., 2011; Dris et al., 2015; Leslie et al., 2017; Talvitie et al., 2017; Carr et al., 2016; Magnusson and Norén, 2014; Mason et al., 2016; Michielssen, 2016; Murphy et al., 2016; Talvitie et al., 2015; Estahbanadi et al., 2016; Mintenig et al., 2017; Ziajahromi et al., 2017; Sutton et al., 2016; Dyachenko et al., 2017; Talvitie et al., 2017; Talvitie and Heinonen, 2014; Gündoğdu et al., 2018; Kalčiková et al., 2017; Gies et al., 2018; Simon et al., 2018; Wisniowska et al., 2018; Yang et al., 2019; Bayo et al., 2019; Long et al., 2019; Blair et al., 2019; Xu et al., 2019; Lv et al., 2019; Liu et al., 2019; Wolff et al., 2019; Cnley et al., 2019; Magni et al., 2019).

\begin{tabular}{|c|c|c|c|c|c|c|}
\hline Reference & $\begin{array}{l}\text { Map } \\
\text { locations }\end{array}$ & MPs concentration & $\begin{array}{l}\text { Lower size limit } \\
\text { for fractionation } \\
\mu \mathrm{m}\end{array}$ & Type of the WWTP & $\begin{array}{l}\text { Retention/ } \\
\text { Efficiency }\end{array}$ & Country \\
\hline Lares et al., 2018 [143] & 1 & 1.05 particles/L & 250 & Primary and secondary & $\begin{array}{l}\text { CAS 99\%, } \\
\text { MBR 99.4\% }\end{array}$ & Finland \\
\hline $\begin{array}{l}\text { Magnusson and Norén, } \\
2014[112]\end{array}$ & 2 & 0.00825 particles/L & 300 & $\begin{array}{l}\text { Mechanical, chemical and } \\
\text { biological treatment }\end{array}$ & $99.9 \%$ & Sweden \\
\hline Dyachenko et al., 2017 [144] & 3 & 0.02 particles/L & 125 & Primary, secondary and tertiary & n.a. & USA \\
\hline Mason et al., 2016 [114] & 4 & 0.05 particles/L & 125 & 17 WWTPs, Tertiary & n.a. & USA \\
\hline Murphy et al., 2016 [117] & 5 & 0.25 particles $/ \mathrm{L}$ & 11 & Primary and secondary & $98 \%$ & UK \\
\hline Carr et al., 2016 [111] & 6 & 0.88 particles $/ \mathrm{m}^{3}$ & 45 & Primary, secondary and tertiary & $99.9 \%$ & USA \\
\hline Ziajahromi et al., 2017 [140] & 7 & 0.28 particles $/ \mathrm{L}$ & 25 & Primary, secondary and tertiary & $92 \%-99 \%$ & Australia \\
\hline Ziajahromi et al., 2017 [140] & 7 & 0.48 particles $/ \mathrm{L}$ & 25 & Primary and secondary & $89 \%$ & Australia \\
\hline Ziajahromi et al., 2017 [140] & 7 & 1.54 particles/L & 25 & Primary & $66 \%$ & Australia \\
\hline $\begin{array}{l}\text { Michielssen et al., } 2016 \\
{[115]}\end{array}$ & 8 & $\begin{array}{l}0.5 \text { to } 5.9 \text { particles/L } \\
\text { (incl. all textile fibers) }\end{array}$ & 20 & $\begin{array}{l}2 \text { WWTPs: primary, secondary } \\
\text { and tertiary }\end{array}$ & $95 \%-99 \%$ & USA \\
\hline $\begin{array}{l}\text { Mintenig et al., } 2014 \text { and } \\
2017 \text { [116] [127] }\end{array}$ & 9 & 0.1 to 10.1 particles $/ \mathrm{L}$ & 20 & $\begin{array}{l}12 \text { WWTPs: mostly secondary } \\
\text { and tertiary }\end{array}$ & $97 \%$ & Germany \\
\hline Talvitie et al., 2015 [118] & 10 & $\begin{array}{l}13.5 \text { particles/L (incl. } \\
\text { all textile fibers) }\end{array}$ & 20 & Primary, secondary and tertiary & $97.6 \%$ & Finland \\
\hline Leslie et al., 2017 [33] & 11 & 9 to 91 particles/L & 0.7 & 7 WWTPs & $72 \%$ & Netherlands \\
\hline Browne et al., 2011 [28] & 12 & 1 particles/L & (filtered) & Primary, secondary and tertiary & n.a. & Australia \\
\hline Dris et al., 2015 [28] & 13 & 14 to 50 particles/L & 100 & Secondary & $83 \%-95 \%$ & France \\
\hline Carr et al., 2016 [111] & 14 & 90 particles/L & $90-300$ & Primary, secondary and tertiary & $95 \%-99 \%$ & USA \\
\hline $\begin{array}{l}\text { Talvitie and Heinonen } 2014 \\
\text { [145] }\end{array}$ & 15 & 70 Particles/L & 20 & n.a & $95.6 \%$ & Russia \\
\hline Gündoğdu et al., 2018 [146] & 16 & 7.02 particles/L & n.a. & Secondary & $73 \%$ & $\begin{array}{l}\text { Turkey } \\
\text { (Seyhan) }\end{array}$ \\
\hline
\end{tabular}




\section{Continued}

\begin{tabular}{|c|c|c|c|c|c|c|}
\hline Gündoğdu et al., 2018 [146] & 17 & 4.11 particles/L & n.a. & Secondary & $79 \%$ & $\begin{array}{l}\text { Turkey } \\
\text { (Yüreğir) }\end{array}$ \\
\hline $\begin{array}{l}\text { Estahbanadi and Fahrenfeld } \\
2016[116]\end{array}$ & 18 & $\begin{array}{l}0.028 \text { to } 0.44 \\
\text { particles/L }\end{array}$ & $250-500$ & Primary and secondary & n.a. & USA \\
\hline Kalčiková et al., 2017 [147] & 19 & 0.021 particles/L & 37 to 95 & Primary (Mechanical and Biological) & $87 \%$ & Slovenia \\
\hline Simon et al., 2018 [148] & 20 & 54 particles/L & 10 to 500 & - & $98.3 \%$ & Denmark \\
\hline Sutton et al., 2016 [141] & 21 & 0.071 particles/L & 125 & Primary and secondary & n.a. & USA \\
\hline Michielssen et al., 2016 [115] & 22 & 5.9 particles/L & 20 & Primary and secondary & $93.8 \%$ & $\begin{array}{l}\text { USA } \\
\text { (Detroit) }\end{array}$ \\
\hline Michielssen et al., 2016 [115] & 23 & 37.4 particles/L & 20 & Primary and secondary & $89.8 \%$ & $\begin{array}{l}\text { USA } \\
\text { (Northfield) }\end{array}$ \\
\hline Wisniowska et al., 2018 [150] & 25 & 0.028 to 0.96 particles/L & n.a. & n.a. & $95 \%-99 \%$ & Poland \\
\hline Yang et al., 2019 [151] & 26 & 0.59 particles/L & 50 & Primary and secondary & $95 \%$ & $\begin{array}{l}\text { China } \\
\text { (Beijing) }\end{array}$ \\
\hline Bayo et al., 2019 [152] & 27 & 0.25 particles/L & n.a & Primary & $90.3 \%$ & $\begin{array}{l}\text { Spain } \\
\text { (Cartagena) }\end{array}$ \\
\hline Long et al., 2019 [153] & 28 & 0.20 e 1.73 items/L & 28.3 & Primary and secondary & $97.8 \%$ & $\begin{array}{l}\text { China } \\
\text { (Xiamen) }\end{array}$ \\
\hline Blair et al., 2019 [154] & 29 & $<1$ and 3 particles/L & 300 & Tertiary & $96 \%$ & UK \\
\hline Xu et al., 2019 [155] & 30 & 9.04 particles/L & 1000 & Primary and secondary & $97.2 \%$ & $\begin{array}{l}\text { China } \\
\text { (Changzhu) }\end{array}$ \\
\hline Liu et al., 2019 [157] & 32 & 28.4 particles/L & 100 & Primary and secondary & $64.4 \%$ & China \\
\hline Wolff et al., 2019 [158] & 33 & 59 and 30 particles/L & 10 & Primary and secondary & n.a & Germany \\
\hline Conley et al., 2019 [159] & 34 & $\begin{array}{l}3.7,17.6 \text { and } 17.2 \\
\text { particles/L }\end{array}$ & 23 & Primary and secondary & $\begin{array}{l}97.6 \%, \\
85.2 \%, \\
85.5 \%\end{array}$ & $\begin{array}{l}\text { USA } \\
\text { (South } \\
\text { Carolina) }\end{array}$ \\
\hline Magni et al., 2019 [160] & 42 & 0.4 particles/L & 8 & Primary, Secondary and tertiary & $84 \%$ & Italy \\
\hline
\end{tabular}

${ }^{a}$ Numbers given in the second column coincide with the numbers in the site map of Figure 6 , showing the locations of the studies on a world map.

filters and continuous backwash sand filters [120]. Also, Sutton et al. commented that plants with tertiary treatment stages such as with granular filtration do not always display lower concentrations of microplastics than plants with solely secondary treatment processes [141]. Furthermore, Primpke et al. showed that a post-filtration treatment reduced the microplastic concentration by more than $70 \%$, but was only efficient with particles $>100 \mu \mathrm{m}[161]$.

Carr et al. have performed a study on 8 water treatment plants in South California [111]. Mason et al. looked at 17 wastewater treatment plants in the state's New York, California, Ohio and Wisconsin, in the years 2013-2015. They found that on the average the effluent contained less than 1 particle of microplastic per L, with fibers (59\% overall) and plastic fragments (33\% overall) being the domi- 
nant contributors and with micropellets making up 1\% of the mix [114]. Again, there is no clear-cut dependence of the concentration of microplastic in the effluent on whether special filtration techniques are used as a tertiary treatment stage [111] Nevertheless, Mahon's studies from 7 wastewater treatment plants in Ireland seem to suggest that also the anaerobic digestion step may be contributing significantly to the removal of microplastics [113]. J. Talvitie et al. have given most likely the most detailed study to date on the removal efficiency of different advanced tertiary stage treatment methods [109]. A very detailed study looks at the removal of microlitter along the different treatment steps of the largest WWTP in Finland, situated in Viikinmäki and serving 800,000 inhabitants of the Helsinki metropolitan area [109]. A typical day of the study saw $1.93 \times 10^{11}$ particles of microlitter carried into the WWTP. Of these $98.4 \%$ were retained in the pre-treatment step which consists of a coarse screening $(10 \mathrm{~mm})$, chemical treatment and a primary sedimentation [109]. Of the $3.07 \times 10^{9}$ particles of microlitter remaining in the water, $88.1 \%$ are retained in the subsequent activated sludge process. This is followed by a tertiary treatment through a biologically active filter (BAF), where $46.2 \%$ of the remaining microlitter particles are retained, leading to an effluent loaded with $1.97 \times 10^{8}$ particles of microlitter [109]. The microplastic load of the effluent was reported to vary between $1.7 \times 10^{6}$ to $1.4 \times$ $10^{8}$ particles per day, with $270,000 \mathrm{~m}^{3}$ water treated [109]. This can be compared to daily microplastic effluent loads of two large secondary WWTPs in USA and UK with $6.5 \times 10^{7}$ particles of microplastic [in $260.954 \mathrm{~m}^{3}$ of treated water [117]] and $0.93 \times 10^{6}$ particles of microplastic [calcd. value in $1.060,000 \mathrm{~m}^{3}$ of treated water, [111]]. Another study comes from Finland, where wastewater and sludge samples were collected from the Kenkäveronniemi WWTP, situated near the city of Mikkeli [143]. The treatment plant purifies $10,000 \mathrm{~m}^{3}$ wastewater per day and features screening, grit separation, primary separation, biological treatment with activated sludge, final sedimentation and disinfection [143]. Here, also the effect of a pilot-scale membrane bioreactor as a tertiary treatment was studied. The bioreactor treats $3 \mathrm{~m}^{3}$ of wastewater per day. The Kenkäveronniemi WWTP had a microplastics removal efficiency of overall $98.3 \%$, with a removal efficiency of $89.8 \%$ and $99.1 \%$ for particles and fibers, respectively, leading to a concentration of 1000 microplastics per $\mathrm{m}^{3}$ of effluent, comprising of fibers and particles in equal measure. The membrane bioreactor released 400 microplastics per $\mathrm{m}^{3}$ of effluent.

Ziajahromi et al. give a detailed study, where the effectiveness of primary, secondary and tertiary WWTPs in Sydney, Australia, to retain microplastics is compared [140]. The primary WWTP involves screening, grit removal and sedimentation, the secondary WWTP adds to these processes a secondary aeration, sedimentation and UV disinfection, while the tertiary WWTP operates with screening, sedimentation, biological treatment, flocculation, disinfection, ultrafiltration and reverse osmosis [140]. The primary WWTP serving 1,000,000 inhabitants contains about $1500 \mathrm{MP}$ per $\mathrm{m}^{3}$ in its effluent leading to a discharge 
of $4.6 \times 10^{8} \mathrm{MPs}$ per day [calcd. value for $308,000 \mathrm{~m}^{3}$ treated water, [140]] into the deep ocean. The secondary WWTP serves 67,130 inhabitants and shows $1440 \mathrm{MP}$ per $\mathrm{m}^{3}$ treated wastewater after the primary treatment stage, which is reduced to $480 \mathrm{MP}$ per $\mathrm{m}^{3}$ in the final effluent. The estimated discharge of MPs in the final effluent is $8.2 \times 10^{6}$ particles per day [calcd. value for $17,000 \mathrm{~m}^{3}$ treated water, [140]]. The tertiary WWTP serving 150,870 inhabitants showed 2200 MPs per $\mathrm{m}^{3}$ effluent after the primary stage, which was decreased to 280 MPs per $\mathrm{m}^{3}$ effluent after ultrafiltration and to $210 \mathrm{MPs}$ per $\mathrm{m}^{3}$ after reverse osmosis. This leads to discharges of $3.6 \times 10^{6}$ MPs and $1.0 \times 10^{7}$ MPs per day through the routes of ultrafiltration and reverse osmosis, respectively [with $13,000 \mathrm{~m}^{3}$ and $48,000 \mathrm{~m}^{3}$ water treated, respectively, [140]]. The study of Ziajahromi shows one of few examples where the increase of the number of the treatment stages led to a decrease of MP concentration.

Other notable studies are a one-day investigation carried out at Central WWTP of Vodokanal in St. Petersburg, Russia. It was found that the influx carried a heavy load of 467 fibers and 160 synthetic particles per L. After mechanical treatment, the load was reduced to 33 fibers and 21 synthetic particles per $\mathrm{L}$, and at the last purification sampling point the load was reduced further to $16 \mathrm{fi}$ bers and 7 synthetic particles per L. Although microplastics were found to be withheld in the WWTP, the final microplastic concentration remained significant [145]. Other studies have been carried out with European water treatment plants [35] such as in the Netherlands, where the Leslie et al. found an average retention rate of $72 \%$ in the wastewater sludge [33].

Apart from plastic microbeads, plastic fibers, and smaller particles resulting from the break-down of larger particles, tire and road wear particles (TRWP) contribute to the overall microplastic load [15] [26] [165] [166]. To assess TRWP in the Seine watershed, Unice et al. based their model on an average wastewater treatment removal efficiency of the particles of 95\% [132], where the fraction of urban run-off directed to combined sewers was set at $75 \%$, with rural runoff going into grassed ditches and swales. All the above was modeled to contribute to the removal of 8351 tons TRWP in 2008 out of 27,607 tons TRWP released that year (30\% of the total). Due to their relatively high density of $1.2-1.3 \mathrm{~g} / \mathrm{cm}^{3}$ [166], it is expected that TRWP would collect in the wastewater sludge. It was understood that the TRWP containing wastewater sludge would be reused on soil or incinerated [132]. TWRP are difficult to identify in samples, potentially also because of their small average size, estimated at 5 - $25 \mu \mathrm{m}$ [167].

\section{Microplastics in Sewage Sludge}

With the waste-water passing through a water treatment plant, the major portion of microplastics is retained in the sewage sludge [55] [140]. High concentrations of microplastics in WWTP sludge samples have been revealed in many studies [36] [55] [111] [113] [152] [168] [169] [170]. In their study, Mahon et al. [113] found microplastic in the sludge in concentrations of 4.20 to $15.4 \times 10^{3}$ 
particles $\mathrm{kg}^{-1}$ dry sludge. Lassen et al. [36] reported that sludge from WWTPs studied in Germany contains 1.00 to $24.0 \times 10^{3} \mathrm{MP}$ particles $(<10 \mathrm{~mm})$ per kg of dry sludge. A rigorous study of microplastic content in sludge from 8 WWTPs in Norway (Oslo, Stavanger, Tromsø, Federickstand, among others) serving altogether 1,500,000 inhabitants and producing about 100,000 tons of sludge revealed an overall average plastic abundance of 6077 particles $\mathrm{kg}^{-1}(\mathrm{dw})$, of which $37.6 \%$ were beads, $31.8 \%$ fragments, and $28.9 \%$ fibers. The most common polymer constituents were found to be polyethylene (30.5\%), polyethylene terephthalate (26.7\%) and polypropylene (20.3\%) [170]. A comparison of microplastic concentrations in different study locations is given below in Table 2. Here, Sujathan et al. report a very high count of microplastic particles at $4.95 \times 10^{5} \mathrm{per} \mathrm{kg}$ $(\mathrm{dw})$ in return activated sludge from a treatment plant in Seelze, Germany [171]. In the study, microplastics as small as $0.48 \mu \mathrm{m}$ could be identified, which may mean that many microplastic particles in WWTP sludge are indeed small and escape detection [170].

It must be noted that while sewage sludge is added to soil, smaller amounts of sludge can also be incinerated. Also, an appreciable quantity, up to $45 \%$ [109] [117] [128] of microplastics, especially those of low density such as LDPE and

Table 2. Summary of significant studies on microplastic content in sewage sludge.

\begin{tabular}{|c|c|c|c|c|c|}
\hline Specific Location & Map locations & Country & MP size range & $\begin{array}{c}\text { MP concentration } \\
\text { (particles } \mathrm{kg}^{-1} \text { d.w.b and w.wc) }\end{array}$ & References \\
\hline (7 WWTPs,) & 35 & Ireland & $250 \mu \mathrm{m}-4 \mathrm{~mm}$ & $4196-15,385^{\mathrm{a}}$ & Mahon et al., 2017 [113] \\
\hline (7 WWTPs, ) & 11 & Netherlands & $0.7 \mu \mathrm{m}-5 \mathrm{~mm}$ & $370-950^{b}$ & Leslie et al., [33] \\
\hline Lysekil & 2 & Sweden & $300 \mu \mathrm{m}-5 \mathrm{~mm}$ & $16.7^{\mathrm{a}} \times 10^{4}$ & Magnusson and Norén, 2014 [112] \\
\hline Ithaca, New York & 36 & USA & No Data & About $1000-4000^{\mathrm{a}}$ & Zubris and Ricahrd, 2017 [19] \\
\hline Los Angeles County & 14 & USA & $<5 \mathrm{~mm}$ & 5000 & Carr et al., 2016 [111] \\
\hline (28 WWTPs,) & 37 & China & $37 \mu \mathrm{m}-5 \mathrm{~mm}$ & $1565-56,386^{\mathrm{b}}$ & Li et al., 2018 [176] \\
\hline Oldenburg & 9 & Germany & $<5 \mathrm{~mm}$ & 1000 to $24,000^{\mathrm{b}}$ & Mintening et al., 2014, 2017 [116] [117] \\
\hline Seelze & 38 & Germany & 20 to $100 \mu \mathrm{m}$ & $495,000^{\mathrm{b}}$ & Sujathan et al., 2017 [170] \\
\hline Glasgow & 5 & UK & $1.34-1.62 \mathrm{~mm}$ & About $2000^{c}$ & Murphy et al., 2016 [117] \\
\hline Mikkeli & 1 & Finland & $<1 \mathrm{~mm}$ & $8.2-301.4^{\mathrm{c}}$ & Lares et al., 2018 [143] \\
\hline Vancouver & 24 & Canada & $64 \mu \mathrm{m}$ & $4400^{c}$ & Gies et al., 2018 [149] \\
\hline (10 WWTPs) & 39 & Norway & $54 \mu \mathrm{m}$ to $5 \mathrm{~mm}$ & $6077^{b}$ & Lusher et al., 2018 [169] \\
\hline Jiangsu & 40 & China & 25 to $>500 \mu \mathrm{m}$ & 1.6 and $0.7^{c}$ & Lv et al., 2019 [156] \\
\hline Wuhan & 41 & China & 100 to $800 \mu \mathrm{m}$ & $24,030^{\mathrm{b}}$ & Liu et al., 2019 [157] \\
\hline Beijing & 26 & China & $681.46 \mu \mathrm{m}$ & $95.16^{\mathrm{a}}$ & Yang et al., 2019 [151] \\
\hline Italy & 42 & Italy & $0.5-0.1 \mathrm{~mm}$ & $113,000^{\mathrm{b}}$ & Magni et al., 2019 [160] \\
\hline
\end{tabular}

${ }^{a}$ Numbers given in the second column coincide with the numbers in the site map of Figure 6 , showing the locations of the studies on a world map. ${ }^{b} \mathrm{DM}$, dry matter. 'The unit is particles $\mathrm{kg}^{-1}$ wet weight and the dry weights of the wet sewage sludge samples were all below $1 \%$. 
PP, can be separated off in the primary steps of the wastewater treatment, in grit traps and during grease skimming. These separated wastes are usually put into landfills or are incinerated [111] [170].

The application of sludge to agricultural soils and municipal green areas as well as its use by soil producers in certain parts of the world raises the concentration of microplastics in soils significantly. In addition, microplastics are entering soil via plastic mulching, irrigation with grey water, and through run-offs. Also, air movement contributes to the dissemination of microplastics in farming areas [29] [172]. The occurrence and fate of microplastics in soil are less studied [80] [172] [173] [174] [175] [176] than of microplastics in the marine environment. It has been calculated that in Norway alone, 500 billion $\left(5 \times 10^{11}\right)$ pieces of microplastic find their way into the soil via sewage sludge applied to agricultural soils [170]. This compares with an estimated $1.56 \times 10^{14}$ plastic particles per year entering Chinese soil [177], and 300,000 and 430,000 tons/year of plastic distributed over European and North American agricultural land [173] [178]. While plastics structurally weather under the influence of humidity, temperature, UV-radiation and wind [80], they remain chemically intact in the soil for long periods of time [179], with slow chemical oxidation and UV driven bond scission being the two main degradation mechanisms reported [9].

In the WWTP, sludge undergoes prior steps such as thickening and dewatering, which can involve a centrifugation step. This is often followed by digestion steps, which can include anaerobic digestion or aerobic digestion/composting. It has been shown that a fraction of up to $20 \%$ of the microplastic can be recycled back into the reject water during the sludge dewatering step [33]. The fate of microplastics in thermal treatment processes such as in the Cambi process (i.e., at $160^{\circ} \mathrm{C}$ ) and including incineration has not been studied in detail. Mahon et al. have noted a potential shredding of MPs in lime stabilization processes, leading to smaller sized MPs. MPs having gone through the sludge thermal drying process showed signs of melting and blistering [113]. Thermoplastic containing microbeads from rinse-off cosmetics have been found to change shape and morphology at temperatures as low as $85^{\circ} \mathrm{C}$. Temperature cycling of these microbeads between $25^{\circ} \mathrm{C}$ and $100^{\circ} \mathrm{C}$ on silica gel as simulated sandy soil led to fragmentation of the beads [180]. Synthetic fibers seem to be more ubiquitous and more indestructible. Rom et al. have looked at polylactide microfibers and have found that they were not biodegraded by treatment with activated sludge under mesophilic $\left(36^{\circ} \mathrm{C}\right)$ or thermophilic $\left(56^{\circ} \mathrm{C}\right)$ conditions, even after 4 weeks [181].

\section{Microplastics, Wastewater Treatment Plants and Future Developments}

A prognosis of the scale of release of microplastics into the environment in the future may reflect on a number of variables. Two are future legislation involving plastics in consumer products and the development of wastewater treatment 
processes. A third important factor is the advancement of research in the analysis of micro- and nanoplastics in the environment and a better understanding of the impact of such plastics.

Significant legislative progress has been made in the reduction of microplastics in personal care products as the use of microplastic beads in these has been banned in some countries and manufacturers have started to phase them out [182] [183] [184]. Already today microbeads are made of cellulose derivatives, polylactide resins, or waxes (see Figure 7) that degrade more readily in the environment, oftentimes leading to more innocuous end-products. It is anticipated that the emission of microplastics via sewage water will be reduced somewhat as a consequence of further legislative efforts to prohibit the use of microbeads in cosmetic products [44]. As microplastic beads are not the main contributor to microplastics in the environment, this legislative effort may not be enough. The ban of single-use plastics in the EC countries by 2021 will contribute further to a containment of microplastic wastes. Other countries such as Malaysia and China have announced similar bans to come into effect by 2030, while Ruanda, Kenya, China, Romania, Bangladesh and India are among the 51 countries that have already imposed a complete ban on single-use LDPE plastic bags [185]. Polystyrene containing foam food containers have been banned in China, India and Zimbabwe, among other countries (see also Table 3 ). A remaining problem will

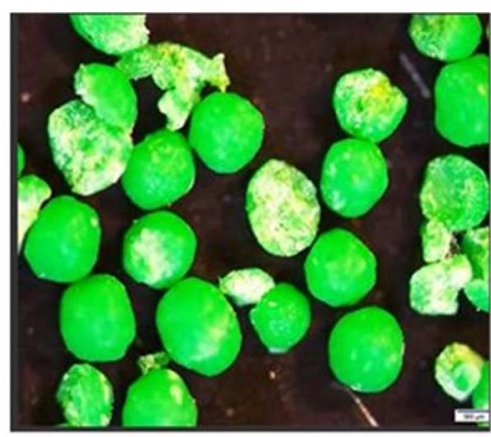

(a)

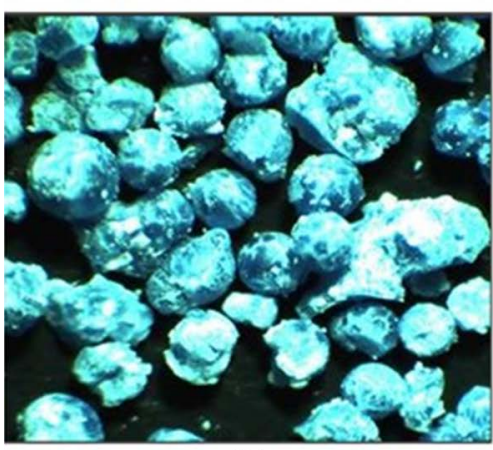

(c)

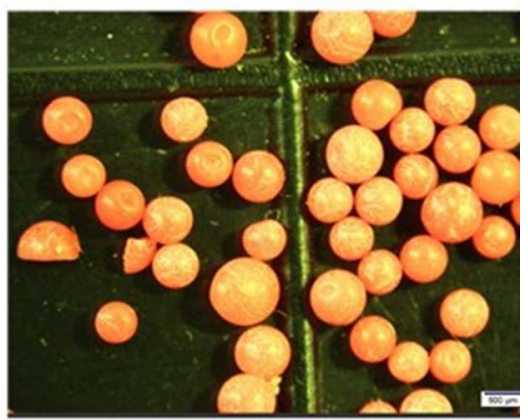

(b)

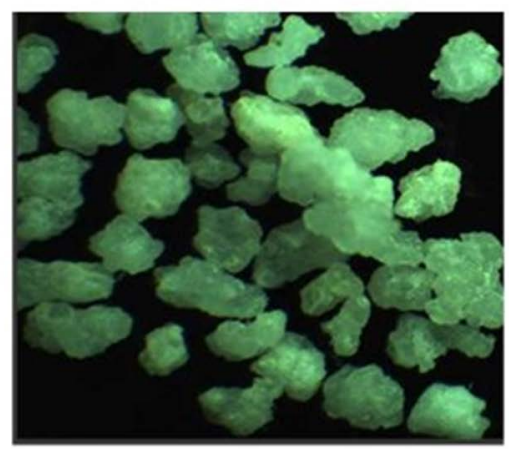

(d)

Figure 7. Microbeads isolated from defoliating cosmetics commercially available in the United Arab Emirates, as seen through an optical microscope. By far, most of the microbeads found in the study [180] were composed of constituents other than synthetic, nonnatural polymers such as microcrystalline cellulose or wax. As ascertained by infrared spectroscopy, only in the photo (c) are the microbeads composed of polyethylene. 
Table 3. Summary of significant regulation set on the sale, manufacture and import of products containing plastic microparticles across the world until July 2018, see also: Hurley et al. [174] Wilkinson et al. [186].

\begin{tabular}{|c|c|c|c|}
\hline Country & $\begin{array}{l}\text { Implementation } \\
\text { Date }\end{array}$ & Regulation & Comments \\
\hline Canada & 18-Jul & $\begin{array}{l}\text { Changes to the Canadian } \\
\text { Environmental Protection Act }\end{array}$ & $\begin{array}{l}\text { The government has imposed a ban on the sale of microbeads } \\
\text { containing shower gels, toothpaste and scrubs since July } 1,2018 \text {. } \\
\text { Furthermore, the production of microbeads containing the listed items } \\
\text { is banned six months before the sales ban. The ban list also includes } \\
\text { all-natural and non-prescription drugs that contain microplastics. }\end{array}$ \\
\hline United Kingdom & Oct. 2017 & Newly proposed legislation & $\begin{array}{l}\text { Prohibits the sale and manufacture of all those cosmetics and personal } \\
\text { care products that contain microplastics and materials hazardous to the } \\
\text { marine environment [187]. }\end{array}$ \\
\hline USA & 17-Jul/Jan. 2018 & Microbeads free water act of 2015 & $\begin{array}{l}\text { Prohibits the manufacture and interstate commerce of all those } \\
\text { cosmetic products that intentionally added plastic particles }>5 \mathrm{~mm} \text { in } \\
\text { diameter. Manufacture ban on microbeads containing cosmetic } \\
\text { products since July } 2017 \text { and a sales ban since January } 2018 \text {. } \\
\text { (Microbeads Free Waters Act of 2015). }\end{array}$ \\
\hline France & Jan. 2018 & Newly proposed legislation & $\begin{array}{l}\text { The sale of cosmetic products containing microplastics and cotton buds } \\
\text { having plastic stems is banned in France. }\end{array}$ \\
\hline New Zealand & 18-Jul & $\begin{array}{l}\text { Changes to the Waste } \\
\text { Minimization At of } 2008\end{array}$ & $\begin{array}{l}\text { The manufacture and sale of microplastic containing personal care } \\
\text { products is banned and a penalty will be imposed on any entity found to } \\
\text { be involved in a breach of the ban. (Waste Minimization Act of 2008). }\end{array}$ \\
\hline China, Taiwan & Jan. 2018 & Newly proposed legislation & $\begin{array}{l}\text { Ban on the import and manufacture of microbead containing rinse-off } \\
\text { cosmetics; a ban of sale of such products was put into place in July } 2018 \text {. }\end{array}$ \\
\hline South Korea & 17-Jul/July 2018 & $\begin{array}{l}\text { Regulation on safety Standards of } \\
\text { Cosmetics }\end{array}$ & $\begin{array}{l}\text { Ban on the manufacture of microplastic containing personal care } \\
\text { products from July } 2017 \text { and a ban of sale from July } 2018 \text { [188]. }\end{array}$ \\
\hline Sweden & 1-Jul-18 & $\begin{array}{l}\text { Proposed by the Swedish Chemical } \\
\text { Agency }\end{array}$ & $\begin{array}{l}\text { Ban on the manufacture, import and sale of microbeads in rinse-off } \\
\text { cosmetics. }\end{array}$ \\
\hline
\end{tabular}

be microplastics derived from textile fibers and from tire and road wear particles (TRWPs).

The topic of removing microplastics in wastewater has only come up in the last decade or so. Many modern wastewater treatment plants have shown a retention rate of $95 \%$ - 99\% (see Table 1). There is room for improvement in filtration and flotation techniques. Membrane filtration technology can remove from $99.4 \%$ to $99.9 \%$ of microplastics [112] [143] [156] from wastewater that has undergone preliminary processing. These techniques have to be balanced with the necessity of high water through-put at an acceptable cost. Existing water treatment plants may be refitted accordingly. Clearly, it must be noted that up to $80 \%$ of the wastewater worldwide is draining off into the environment untreated. In addition, regions microplastics disbursed in the environment on land such as TRWPs may be moved only very periodically via sudden and uncontrolled run-offs, such as in many of the arid regions in the world.

The advancement in scientific knowledge in microplastics and their interaction with the environment has led to the development of new analytical methodologies concerning the sampling and characterization of the materials. This new knowledge base will contribute significantly towards minimizing the emis- 
sion of microplastics into the environment. Nevertheless, often, it remains difficult to compare directly different studies from different research groups. Frequently, estimates from different groups on regional and worldwide abundance of microplastics in the aqueous environment based on studies restricted to but a few areas differ widely. Also, it has been noted previously [139] that different studies on the occurrence of microplastics in waterbodies reported the data either in particles per volume or as particles per surface area of the waterbodies [189] [190], where there is not always a meaningful conversion between the two units. Therefore, a more rigorous standardization of methodologies and reporting is needed. Much less has been done on the fate of microplastics in soils.

Worrisome also seems the lack of exact data on the occurrence of nanoplastics in the environment and their uptake in organisms, where an adequate methodology in sampling and characterization needs to be disseminated. There is a concern about small sized plastics in drinking water, especially in bottled water, which was thought to derive from the production of plastic bottles [191], but because of the material composition of some of the microplastics found in the drinking water now is thought to partially come from external sources [192]. Recently, nano- and microplastics in form of fragments and fibers have also been found in honey [193], beer [194] and salt [195].

\section{Conclusion}

WWTPs constitute the last line of defense in our battle to reduce emissions of microplastics into the environment. Clearly, a very large percentage of microplastics are retained by WWTPs and thus WWTPs lead to a much reduced, channeled emission of microplastics. Primary stages of WWTPs have been recorded to remove $78 \%$ - $98 \%$ of microplastics, secondary stages make for another $7 \%-20 \%$ retained microplastics. The contribution of tertiary stages varies. So far, all tertiary treatment methods such as ultrafiltration and reverse osmosis lead to the discharge of MPs in the effluent so that there is effectively no commercial separation method put into place that leads to zero emission of microplastics from WWTPs. Moreover, while by far the most MPs are already retained in the primary stage, the fate of the remaining MPs through subsequent treatment stages is not always easy to predict [143] as diverse feedback cycles exist. Water from dewatering sludge and water from rinsing removed solids and grease, which are mixed back into the influent, may carry appreciable amounts of MPs [109] [143]. Much of the microplastics end up in the sludge. Therefore, the fate of the sludge also determines the fate of the embedded microplastics, and it is here that more research needs to be done in order to avoid exposure of the soil to highly mobile plastics or constituent compounds of plastics.

\section{Acknowledgements}

The authors acknowledge Eng. Wajeeh Kittaneh, Department of Geology, United Arab Emirates University for his help with the photos shown in Figure 7. 


\section{Conflicts of Interest}

The authors declare no conflicts of interest regarding the publication of this paper.

\section{References}

[1] Gorman, M. (1993) Environmental Hazards-Marine Pollution. ABC-CLIO, Santa Barbara.

[2] Beall, G. (2009) By Design: World War II, Plastics, and NPE. https://www.plasticstoday.com/content/design-world-war-ii-plastics-and-npe/2725 7907612254

[3] PlasticsEurope (2015) Plastics-The Facts 2015. An Analysis of European Plastics Production, Demand and Waste Data 2015. https://www.statista.com/statistics/282732/global-production-of-plastics-since-1950

[4] Žmak, I. and Hartmann, C. (2017) Current State of the Plastic Waste Recycling System in the European Union and in Germany. Tehnički Glasnik, 11, 138-142.

[5] Ryan, P.G. (2015) A Brief History of Marine Litter Research. In: Bergmann, M., Gutow, L. and Klages, M., Eds., Marine Anthropogenic Litter, Springer, Berlin, Open Chpt. 1, 1-28. https://doi.org/10.1007/978-3-319-16510-3_1

[6] Kenyon, K.W. and Kridler, E. (1969) Laysan Albatrosses Swallow Indigestible Matter. Auk, 86, 339-343. https://doi.org/10.2307/4083505

[7] Carpenter, E.J. and Smith, K.L. (1972) Plastic on the Sargasso Sea Surface. Science, 175, 1240-1241. https://doi.org/10.1126/science.175.4027.1240

[8] Carpenter, E.J., Anderson, S.J., Harvey, G.R., Miklas, H.P. and Peck, B.B. (1972) Polystyrene Spherules in Coastal Waters. Science, 178, 749-750.

https://doi.org/10.1126/science.178.4062.749

[9] Andrady, A.L. (2011) Microplastics in the Marine Environment. Marine Pollution Bulletin, 62, 1596-1605. https://doi.org/10.1016/j.marpolbul.2011.05.030

[10] Rochman, C.M., Cook, A.-M. and Koelmans, A.A. (2016) Plastic Debris and Policy: Using Current Scientific Understanding to Invoke Positive Change. Environmental Toxicology and Chemistry, 35, 1617-1626. https://doi.org/10.1002/etc.3408

[11] Eriksen, M., Lebreton, L.C.M. and Carson, H.S. (2014) Plastic Pollution in the World's Oceans: More than 5 Trillion Plastic Pieces Weighing over 250,000 Tons Afloat at Sea. PLoS ONE, 9, e111913. https://doi.org/10.1371/journal.pone.0111913

[12] Jambeck, J.R., Geyer, R., Wilcox, C., Siegler, T.R., Perryman, M., Andrady, M., Narayan, A.R. and Law, K.L. (2015) Plastic Input from Land into the Ocean. Science, 80, 768-771. https://doi.org/10.1126/science.1260352

[13] Zhao, S., Zhu, L., Wang, T. and Li, D. (2014) Suspended Microplastics in the Surface Water of the Yangtze Estuary System, China: First Observations on Occurrence, Distribution. Marine Pollution Bulletin, 85, 562-568.

https://doi.org/10.1016/j.marpolbul.2014.06.032

[14] McCormick, A., Hoellein, T.J., Mason, S.A., Schluep, J. and Kelly, J.J. (2014) Microplastic Is an Abundant and Distinct Microbial Habitat in an Urban River. Environmental Science \& Technology, 48, 11863-11871. https://doi.org/10.1021/es503610r

[15] Horton, A.A., Walton, A., Spurgeon, D.J., Lahive, E. and Svendsen, C. (2017) Microplastics in Freshwater and Terrestrial Environments: Evaluating the Current Understanding to Identify the Knowledge Gaps and Future Research Priorities. Science of the Total Environment, 586, 127-141. 
https://doi.org/10.1016/j.scitotenv.2017.01.190

[16] Bowmer, T. and Kershaw, P. (2010) Proceedings of the GESAMP International Workshop on Micro-Plastic Particles as a Vector in Transporting Persistent, Bio-Accumulating and Toxic Substances in the Oceans. In: GESAMP Reports \& Studies, UNESCO-IOC, Paris, 68 p.

[17] Norén, F. (2007) Small Plastic Particles in Coastal Swedish Waters. KIMO Report, Sweden.

[18] Claessens, M., De Meester, S., Van Landuyt, L., De Clerck, K. and Janssen, C.R. (2011) Occurrence and Distribution of Microplastics in Marine Sediments along the Belgian Coast. Marine Pollution Bulletin, 62, 2199-2204. https://doi.org/10.1016/j.marpolbul.2011.06.030

[19] Zubris, K.A. and Richards, B.K. (2005) Synthetic Fibers as an Indicator of Land Application of Sludge. Environmental Pollution, 138, 201-211. https://doi.org/10.1016/j.envpol.2005.04.013

[20] Eerkes-Medrano, D., Thompson, R.C. and Aldridge, D.C. (2015) Microplastics in Freshwater Systems: A Review of Emerging Threats, Identification of Knowledge Gaps and Prioritization of Research Needs. Water Research, 75, 63-82. https://doi.org/10.1016/j.watres.2015.02.012

[21] Koelmans, A.A., Besseling, E. and Shim, W.J. (2015) Nanoplastics in the Aquatic Environment: Critical Review. In: Marine Anthropogenic Litter, Springer International Publishing, Berlin, 325-340. https://doi.org/10.1007/978-3-319-16510-3_12

[22] Cózar, A., Echevarría, F., González-Gordillo, J.I., Irigoien, X., Úbeda, B., Hernández-Leon, S., Palma, A.T., Navarro, S., Garcia-de-Lomas, J., Ruiz, A., Fernández-de-Puelles, M.L. and Duarte, C.M. (2014) Plastic Debris in the Open Ocean. Proceedings of the National Academy of Sciences of the United States of America, 111, 10239-10244. https://doi.org/10.1073/pnas.1314705111

[23] Ter Halle, A., Jeannau, L., Martignac, M., Jardé, E., Pedrono, B., Brach, L. and Gigault, J. (2017) Nanoplastic in the North Atlantic Subtropical Gyre. Environmental Science \& Technology, 51, 13689-13697. https://doi.org/10.1021/acs.est.7b03667

[24] Gigault, J., ter Halle, A., Baudrimont, M., Pascal, P.-Y., Gauffre, F., Phi, T.-L., El Hadri, H., Grassl, B. and Reynaud, S. (2018) Current Opinion: What Is a Nanoplastic? Environmental Pollution, 235, 1030-1034. https://doi.org/10.1016/j.envpol.2018.01.024

[25] Cole, M., Lindeque, P., Halsband, C. and Galloway, T.S. (2011) Microplastics as Contaminants in the Marine Environment: A Review. Marine Pollution Bulletin, 62, 2588-2597. https://doi.org/10.1016/j.marpolbul.2011.09.025

[26] Sundt, P., Schulze, P.-E. and Syversen, F. (2014/2015) Sources of Microplastic Pollution to the Marine Environment. Report No M-321/2015, Mepex for the Norwegian Environment Agency (Miljødirektoratet, 86).

[27] Duis, K. and Coors, A. (2016) Microplastics in the Aquatic and Terrestrial Environment: Sources (with a Specific Focus on Personal Care Products), Fate and Effects. Environmental Sciences Europe, 28, 2. https://doi.org/10.1186/s12302-015-0069-y

[28] Browne, M.A., Crump, P., Niven, S.J., Teuten, E., Tonkin, A., Galloway, T. and Thompson, R. (2011) Accumulation of Microplastic on Shorelines Worldwide: Sources and Sinks. Environmental Science \& Technology, 45, 9175-9179. https://doi.org/10.1021/es201811s

[29] Dris, R., Imhof, H., Sanchez, W., Gasperi, J., Galgani, F., Tassin, B. and Laforsch, C. (2015) Beyond the Ocean: Contamination of Freshwater Ecosystems with (Micro-) 
Plastic Particles. Environmental Chemistry, 12, 539-550. https://doi.org/10.1071/EN14172

[30] Essel, R., Engel, L., Carus, M. and Ahrens, R.H. (2015) Sources of Microplastics Relevant to Marine Protection in Germany. Texte 64/2015 Project No. 31969 Report No. (UBA-FB) 002146/E, Federal Environment Agency.

[31] GESAMP (2015) Sources, Fate and Effects of Microplastics in the Environment: A Global Assessment. In: Kershaw, P.J., Ed., Rep. Stud., GESAMP No. 90-96.

[32] Wentworth, J. and Stafford, C. (2016) Marine Microplastic Pollution. POSTNOTE (528), Houses of Parliament (2016) UK.

https://researchbriefings.parliament.uk/ResearchBriefing/Summary/POST-PN-0528

[33] Leslie, H.A., Brandsma, S.H., van Velzen, M.J.M. and Vethaak, A.D. (2017) Microplastics En Route: Field Measurements in the Dutch River Delta and Amsterdam Canals, Wastewater Treatment Plants, North Sea Sediments and Biota. Environment International, 101, 133-142. https://doi.org/10.1016/j.envint.2017.01.018

[34] Boucher, J. and Friot, D. (2017) Primary Microplastics in the Oceans: A Global Evaluation of Sources. IUCN, Gland, 43 p. https://doi.org/10.2305/IUCN.CH.2017.01.en

[35] Magnusson, K., Eliasson, K., Fråne, A., Haikonen, K., Hultén, J., Olshammar, M., Stadmark, J. and Voisin, A. (2016) Swedish Sources and Pathways for Microplastics to the Marine Environment. Report C183, Swedish Environmental Research Institute, Stockholm (Revised 2017).

[36] Lassen, C., Hansen, S.F., Magnusson, K., Norén, F., Hartmann, N.I.B., Jensen, P.R., Nielsen, T.G. and Brinch, A. (2015) Microplastics-Occurrence, Effects and Sources of Releases to the Environment in Denmark, Environmental Project No. 1973. Danish Ministry of the Environment-Environmental Protection Agency, Denmark, 204.

[37] Corbanie, E.A., Matthijs, M.G.R., van Eck, J.H.H., Remon, J.P., Landman, W.J.M. and Vervaet, C. (2006) Deposition of Differently Sized Airborne Microspheres in the Respiratory Tract of Chickens. Avian Pathology, 35, 475-485.

https://doi.org/10.1080/03079450601028845

[38] Jani, P.U., Florence, A.T. and McCarthy, D.E. (1992) Further Histological Evidence of Gastrointestinal Absorption of Polystyrene Nanospheres in the Rat. International Journal of Pharmaceutics, 84, 245-252. https://doi.org/10.1016/0378-5173(92)90162-U

[39] Florence, A.T., Sakthivel, T. and Toth, I. (2000) Oral Uptake and Translocation of a Polylysine Dendrimer with a Lipid Surface. Journal of Controlled Release, 65, 253-259. https://doi.org/10.1016/S0168-3659(99)00237-0

[40] Florence, A.T. and Hussain, N. (2001) Transcytosis of Nanoparticle and Dendrimer Delivery Systems, Evolving Vistas. Advanced Drug Delivery Reviews, 50, S69-S89. https://doi.org/10.1016/S0169-409X(01)00184-3

[41] Gouin, T., Avalos, J., Brunning, I., Brzuska, K., de Graaf, J., Kaumanns, J., Koning, T., Meyberg, M., Rettinger, K., Schlatter, H., Thomas, J., van Welie, R. and Wolf, T. (2012) Use of Micro-Plastic Beads in Cosmetic Products in Europe and Their Estimated Emissions to the North Sea Environment. SOFW Journal, 141, 40-46.

[42] Dubaish, F. and Liebezeit, G. (2013) Suspended Microplastics and Black Carbon Particles in the Jade System, Southern North Sea. Water, Air, \& Soil Pollution, 224, 1352. https://doi.org/10.1007/s11270-012-1352-9

[43] Pakula, C. and Stamminger, R. (2010) Electricity and Water Consumption for Laundry Washing by Washing Machine Worldwide. Energy Efficiency, 3, 365-382. 
https://doi.org/10.1007/s12053-009-9072-8

[44] Napper, I.E. and Thompson, R.C. (2016) Release of Synthetic Microplastic Fibres from Domestic Washing Machines: Effects of Fabric Type and Washing Conditions. Marine Pollution Bulletin, 112, 39-45. https://doi.org/10.1016/j.marpolbul.2016.09.025

[45] Molhave, L., Schneider, T., Kjaergaard, S.K., Larsen, L., Norn, S. and Jorgensen, O. (2000) House Dust in Seven Danish Offices. Atmospheric Environment, 34, 4767-4779. https://doi.org/10.1016/S1352-2310(00)00104-7

[46] Wright, S.L. and Kelly, F.J. (2017) Plastic and Human Health: A Micro Issue? Environmental Science \& Technology, 51, 6634-6647. https://doi.org/10.1021/acs.est.7b00423

[47] Thompson, R.C., Moore, C.J., vom Saal, F.S. and Swan, S.H. (2009) Plastics, the Environment and Human Health: Current Consensus and Future Trends. Philosophical Transactions of the Royal Society B, 364, 2153-2166. https://doi.org/10.1098/rstb.2009.0053

[48] Galgani, H., Hanke, G., Werner, S. and de Vrees, L. (2013) Marine Litter within the European Marine Strategy Framework Directive ICES. Journal of Marine Science, 70, 1055-1064. https://doi.org/10.1093/icesjms/fst122

[49] Gall, S.C. and Thompson, R.C. (2015) The Impact of Debris on Marine Life. Marine Pollution Bulletin, 92, 170-179. https://doi.org/10.1016/j.marpolbul.2014.12.041

[50] Raju, S., Carbery, M., Kuttykattil, A., Senathirajah, K., Subashchandrabose, S.R., Evans, G. and Thavamani, P. (2018) Transport and Fate of Microplastics in Wastewater Treatment Plants: Implications to Environmental Health. Reviews in Environmental Science and Biotechnology, 17, 637-653. https://doi.org/10.1007/s11157-018-9480-3

[51] Hidalgo-Ruz, V., Gutow, L. and Thiel, R.C.M. (2012) Microplastics in the Marine Environment: A Review of the Methods Used for Identification and Quantification. Environmental Science \& Technology, 46, 3060-3075. https://doi.org/10.1021/es2031505

[52] Van Cauwenberghe, L., Devriese, L., Galgani, F., Robbens, J. and Janssen, C.R. (2015) Microplastics in Sediments: A Review of Techniques, Occurrence and Effects. Marine Environmental Research, 111, 5-17. https://doi.org/10.1016/j.marenvres.2015.06.007

[53] Pitt, J.A., Kozal, J.S., Jayasundara, N., Massarsky, A., Trevisan, R., Geitner, N., Wiesner, M., Levin, E.D. and Di Giulio, R.T. (2018) Uptake, Tissue Distribution, and Toxicity of Polystyrene Nanoparticles in Developing Zebrafish (Danio rerio). Aquatic Toxicology, 194, 185-194. https://doi.org/10.1016/j.aquatox.2017.11.017

[54] Kentin, E. (2018) Restricting Microplastics in the European Union: Process and Criteria under REACH. The European Physical Journal Plus, 133, 425. https://doi.org/10.1140/epjp/i2018-12228-2

[55] EC (2017) EC, Intentionally Added Microplastics in Products: Final Report. European Commission, Brussels.

[56] PlasticsEurope (2016) Plastic-The Facts 2016. https://www.plasticseurope.org/application/files/4315/1310/4805/plastic-the-fact-20 $\underline{16 . p d f}$

[57] Zhang, H.B., Zhou, Q., Xie, Z.Y., Zhou, Y., Tu, C., Fu, C.C., Mi, W.Y., Ebinghaus, R., Christie, P. and Luo, Y.M. (2018) Occurrences of Organophosphorus Esters and Phthalates in the Microplastics from the Coastal Beaches in North China. Science of the Total Environment, 616, 1505-1512. 
https://doi.org/10.1016/j.scitotenv.2017.10.163

[58] Klein, S., Worch, E. and Knepper, T.P. (2015) Occurrence and Spatial Distribution of Microplastics in River Shore Sediments of the Rhine-Main Area in Germany. Environmental Science \& Technology, 49, 6070-6076.

https://doi.org/10.1021/acs.est.5b00492

[59] Zhang, W., Zhang, S., Wang, J., Wang, Y., Mu, J., Wang, P., Lin, X. and Ma, D. (2017) Microplastic Pollution in the Surface Waters of the Bohai Sea, China. Environmental Pollution, 231, 541-548. https://doi.org/10.1016/j.envpol.2017.08.058

[60] Lusher, A.L., Tirelli, V., O’Connor, I. and Officer, R. (2015) Microplastics in Arctic Polar Waters: The First Reported Values of Particles in Surface and Sub-Surface Samples. Scientific Reports, 5, Article No. 14947. https://doi.org/10.1038/srep14947

[61] Di, M. and Wang, J. (2018) Microplastics in Surface Water and Sediments of the Three Gorges Reservoir, China. Science of the Total Environment, 616-617, 1620-1627. https://doi.org/10.1016/j.scitotenv.2017.10.150

[62] Scheurer, M. and Bigalke, M. (2018) Microplastics in Swiss Floodplain Soils. Environmental Science \& Technology, 52, 3591-3598. https://doi.org/10.1021/acs.est.7b06003

[63] Bosker, T., Guaita, L. and Behrens, P. (2018) Microplastic Pollution on Caribbean Beaches in the Lesser Antilles. Marine Pollution Bulletin, 133, 442-447. https://doi.org/10.1016/j.marpolbul.2018.05.060

[64] Monteiro, R.C.P., do Sul, J.A.I. and Costa, M.F. (2018) Plastic Pollution in Islands of the Atlantic Ocean. Environmental Pollution, 238, 103-110. https://doi.org/10.1016/j.envpol.2018.01.096

[65] Gallo, F., Fossi, C., Weber, R., Santillo, D., Sousa, J., Ingram, I., Nadal, A. and Romano, D. (2018) Marine Litter Plastics and Microplastics and Their Toxic Components: The Need for Urgent Preventive Measures. Environmental Sciences Europe, 30, 13. https://doi.org/10.1186/s12302-018-0139-z

[66] Lusher, A.L., McHugh, M. and Thompson, R.C. (2013) Occurrence of Microplastics in the Gastrointestinal Tract of Pelagic and Demersal Fish from the English Channel. Marine Pollution Bulletin, 67, 94-99. https://doi.org/10.1016/j.marpolbul.2012.11.028

[67] Cole, M., Lindeque, P., Fileman, E., Halsband, C., Goodhead, R., Moger, J. and Galloway, T.S. (2013) Microplastic Ingestion by Zooplankton. Environmental Science \& Technology, 47, 6646-6655. https://doi.org/10.1021/es400663f

[68] Desforges, J.-P.W., Galbraith, M. and Ross, P.S. (2015) Ingestion of Microplastics by Zooplankton in the Northeast Pacific Ocean. Archives of Environmental Contamination and Toxicology, 69, 320-330. https://doi.org/10.1007/s00244-015-0172-5

[69] Browne, M.A., Dissanayake, A., Galloway, T.S., Lowe, D.M. and Thompson, R.C. (2008) Ingested Microscopic Plastic Translocates to the Circulatory System of the Mussel, Mytilus edulis (L). Environmental Science \& Technology, 42, 5026-5031. https://doi.org/10.1021/es800249a

[70] Shaw, D.G. and Day, R.H. (1994) Colour- and Form-Dependent Loss of Plastic Micro-Debris from the North Pacific Ocean. Marine Pollution Bulletin, 28, 39-43. https://doi.org/10.1016/0025-326X(94)90184-8

[71] Wright, S.L., Thompson, R.C. and Galloway, T.S. (2013) The Physical Impacts of Microplastics on Marine Organisms: A Review. Environmental Pollution, 178, 483-492. https://doi.org/10.1016/j.envpol.2013.02.031

[72] Bern, L. (1990) Size-Related Discrimination of Nutritive and Inert Particles by 
Freshwater Zooplankton. Journal of Plankton Research, 12, 1059-1067. https://doi.org/10.1093/plankt/12.5.1059

[73] Hämer, J., Gutow, L., Köhler, A. and Saborowski, R. (2014) Fate of Microplastics in the Marine Isopod Idotea Emarginata. Environmental Science \& Technology, 48, 13451-13458. https://doi.org/10.1021/es501385y

[74] Cedervall, T., Hansson, L.A., Lard, M., Frohm, B. and Linse, S. (2012) Food Chain Transport of Nanoparticles Affects Behavior and Fat Metabolism in Fish. PLoS ONE, 7, e32254. https://doi.org/10.1371/journal.pone.0032254

[75] Rillig, M.C. (2012) Microplastic in Terrestrial Ecosystems and the Soil. Environmental Science \& Technology, 46, 6453-6454. https://doi.org/10.1021/es302011r

[76] Mattsson, K., Ekvall, M.T., Hanson, L.A., Linse, S., Malmendal, A. and Cedervall, T. (2014) Altered Behavior, Physiology, and Metabolism in Fish Exposed to Polystyrene Nanoparticles. Environmental Science \& Technology, 49, 553-561. https://doi.org/10.1021/es5053655

[77] Iannilli, V., Di Gennaro, A., Lecce, F., Sighicelli, M., Falconieri, M., Pietrelli, L., Poeta, G. and Battisti, C. (2018) Microplastics in Talitrus Saltator Crustacea, Amphipoda): New Evidence of Ingestion from Natural Contexts. Environmental Science and Pollution Research, 25, 28725-28729. https://doi.org/10.1007/s11356-018-2932-Z

[78] Bouwmeetser, H., Hollman, P.C. and Peters, R.J. (2015) Potential Health Impact of Environmentally Released Micro- and Nanoplastics in the Human Food Production Chain: Experiences from Nanotoxicology. Environmental Science \& Technology, 49, 8932-8947. https://doi.org/10.1021/acs.est.5b01090

[79] Revel, M., Châtel, A. and Mouneyrac, C. (2018) Micro(nano)plastics: A Threat to Human Health? Current Opinion in Environmental Science \& Health, 1, 17-23. https://doi.org/10.1016/j.coesh.2017.10.003

[80] Galloway, T.S. (2015) Micro- and Nano-Plastics and Human Health, In: Bergmann, M., Gutow, L. and Klages, M., Eds., Marine Anthropogenic Litter, Springer, Berlin, 343-366. https://doi.org/10.1007/978-3-319-16510-3_13

[81] Chae, Y. and An, J.-Y. (2017) An, Effects of Micro- and Nanoplastics on Aquatic Ecosystems: Current Research Trends and Perspectives. Marine Pollution Bulletin, 124, 624-632. https://doi.org/10.1016/j.marpolbul.2017.01.070

[82] Hart, M.W. (1991) Particle Captures and the Method of Suspension Feeding by Echinoderm Larvae. The Biological Bulletin, 180, 12-27. https://doi.org/10.2307/1542425

[83] Sjollema, S.B., Redondo-Hasselerharm, P., Leslie, H.A., Kraak, M.H. and Vethaak, A.D. (2016) Do Plastic Particles Affect Microalgal Photosynthesis and Growth? Aquatic Toxicology, 170, 259-261. https://doi.org/10.1016/j.aquatox.2015.12.002

[84] Sussarellu, R., Suquet, M., Thomas, Y., Lambert, C., Fabioux, C., Pernet, M.E.J., Le Goïc, N., Quillien, V., Mingant, C., Epelboin, Y., Corporeau, C., Guyomarch, J., Robbens, J., Paul-Pont, I., Soudant, P. and Huvet, A. (2016) Oyster Reproduction Is Affected by Exposure to Polystyrene Microplastics. Proceedings of the National Academy of Sciences of the United States of America USA, 113, 2430-2435. https://doi.org/10.1073/pnas.1519019113

[85] Hu, L.L., Chernick, M., Hinton, D.E. and Shi, H.H. (2018) Microplastics in Small Waterbodies and Tadpoles from Yangtze River Delta, China. Environmental Science \& Technology, 52, 8885-8893. https://doi.org/10.1021/acs.est.8b02279

[86] Besseling, E., Wegner, A., Foekema, E.M., Van Den Heuvel-Greve, M.J. and Koelmans, A.A. (2013) Effects of Microplastic on Fitness and PCB Bioaccumulation by 
the Lugworm Arenicola marina (L). Environmental Science \& Technology, 47, 593-600. https://doi.org/10.1021/es302763x

[87] Canesi, L., Ciacci, C., Fabbri, R., Balbi, T., Salis, A., Damonte, C., Cortese, K., Caratto, V., Monopoli, M.P., Dawson, K., Bergami, E. and Corsi, I. (2015) Interactions of Cationic Polystyrene Nanoparticles with Marine Bivalve Hemocytes in a Physiological Environment: Role of Soluble Hemolymph Proteins. Environmental Research, 150, 73-81. https://doi.org/10.1016/j.envres.2016.05.045

[88] Au, S.Y., Bruce, T.F., Bridges, W.C. and Klaine, S.J. (2015) Responses of Hyalella azteca to Acute and Chronic Microplastic Exposures. Environmental Toxicology and Chemistry, 34, 2564-2572. https://doi.org/10.1002/etc.3093

[89] Nasser, F. and Lynch, I. (2016) Secreted Protein Eco-Corona Mediates Uptake and Impacts of Polystyrene Nanoparticles on Daphnia magna. Journal of Proteomics, 137, 45-51. https://doi.org/10.1016/j.jprot.2015.09.005

[90] Secretariat of the Convention on Biological Diversity (2012) Impacts of Marine Debris on Biodiversity; Current Status and Potential Solutions. CBD Technical Series 67.

[91] Virsek, M.K., Lovsin, M.N., Koren, S., Krzan, A. and Peterlin, M. (2017) Microplastics as a Vector for the Transport of the Bacterial Fish Pathogen Species Aeromonas salmonicida. Marine Pollution Bulletin, 125, 301-309. https://doi.org/10.1016/j.marpolbul.2017.08.024

[92] Debeljak, P., Pinto, M., Proietti, M., Reisser, J., Ferrari, F.F., Abbas, B., van Loosdrecht, M.C.M., Slat, B. and Herndl, G.J. (2017) Extracting DNA from Ocean Microplastics: A Method Comparison Study. Analytical Methods, 9, 1521-1526. https://doi.org/10.1039/C6AY03119F

[93] Antunes, J.C., Frias, J.G.L., Micaelo, A.C. and Sobral, P. (2013) Resin Pellets from Beaches of the Portuguese Coast and Adsorbed Persistent Organic Pollutants. Estuarine, Coastal and Shelf Science, 130, 62-69. https://doi.org/10.1016/j.ecss.2013.06.016

[94] Pflieger, M., Makoric, P., Virsek, M.K. and Koren, S. (2017) Extraction of Organochlorine Pesticides from Plastic Pellets and Plastic Type Analysis. Journal of Visualized Experiments, 125, e55531. https://doi.org/10.3791/55531

[95] Lee, H., Byun, D.E., Kim, J.M. and Kwon, J.H. (2018) Desorption Modeling of Hydrophobic Organic Chemicals from Plastic Sheets Using Experimentally Determined Diffusion Coefficients in Plastics. Marine Pollution Bulletin, 126, 312-317. https://doi.org/10.1016/j.marpolbul.2017.11.032

[96] Endo, S., Takizawa, R., Okuda, K., Takada, H., Chiba, K., Kanehiro, H., Ogi, H., Yamashita, R. and Date, T. (2005) Concentration of Polychlorinated Biphenyls (PCBs) in Beached Resin Pellets: Variability among Individual Particles and Regional Differences. Marine Pollution Bulletin, 50, 1103-1114.

https://doi.org/10.1016/j.marpolbul.2005.04.030

[97] Avio, C.G., Gorbi, S., Milan, M., Benedetti, M., Fattorini, D., d’Errico, G., Pauletto, M., Bargelloni, L. and Regoli, F. (2015) Pollutants Bioavailability and Toxicological Risk from Microplastics to Marine Mussels. Environmental Pollution, 198, 211-222. https://doi.org/10.1016/j.envpol.2014.12.021

[98] Paul-Pont, I., Lacroix, C., Fernández, C.G., Hégaret, H., Lambert, C., Le Goïc, N., Frère, L., Cassone, A.-L., Sussarellu, R., Fabioux, C., Guyomarch, J., Albentosa, M., Huvet, A. and Soudant, P. (2016) Exposure of Marine Mussels Mylitus spp. to Polystyrene Microplastics: Toxicity and Influence of Fluoranthene Bioaccumulation. Environmental Pollution, 216, 724-737. 
https://doi.org/10.1016/j.envpol.2016.06.039

[99] Batel, A., Borchert, F., Reinwald, H., Erdinger, L. and Braunbeck, T. (2018) Microplastic Accumulation Patterns and Transfer of benzo[a]pyrene to Adult Zebrafish (Danio rerio) Gills and Zebrafish Embryos. Environmental Pollution, 235, 918-930. https://doi.org/10.1016/j.envpol.2018.01.028

[100] Koelmans, A.A., Besseling, E. and Foekema, E.M. (2014) Leaching of Plastic Additives to Marine Organisms. Environmental Pollution, 187, 49-54. https://doi.org/10.1016/j.envpol.2013.12.013

[101] Khaled, A., Rivaton, A., Richard, C., Jaber, F. and Sleiman, M. (2018) Phototransformation of Plastic Containing Brominated Flame Retardants: Enhanced Fragmentation and Release of Photoproducts to Water and Air. Environmental Science \& Technology, 52, 11123-11131. https://doi.org/10.1021/acs.est.8b03172

[102] Leon, V.M., Garcia, I., Gonzalez, E., Samper, R., Fernandez-Gonzalez, V. and Muniategui-Lorenzo, S. (2018) Potential Transfer of Organic Pollutants from Littoral Plastics Debris to the Marine Environment. Environmental Pollution, 236, 442-453. https://doi.org/10.1016/j.envpol.2018.01.114

[103] Holmes, L.A., Turner, A. and Thompson, R.C. (2012) Adsorption of Trace Metals to Plastic Resin Pellets in the Marine Environment. Environmental Pollution, 160, 42-48. https://doi.org/10.1016/j.envpol.2011.08.052

[104] Rochman, C.M., Hentschel, B.T. and Teh, S.J. (2014) Long-Term Sorption of Metals Is Similar among Plastic Types: Implications for Plastic Debris in Aquatic Environments. PLoS ONE, 9, e85433. https://doi.org/10.1371/journal.pone.0085433

[105] Napper, I.E., Bakir, A., Rowland, S.J. and Thompson, R.C. (2015) Characterization, Quantity and Sorptive Properties of Microplastics Extracted from Cosmetic. Marine Pollution Bulletin, 99, 178-185. https://doi.org/10.1016/j.marpolbul.2015.07.029

[106] Cesa, F.S., Turra, A. and Baruque-Ramos, J. (2017) Synthetic Fibers as Microplastics in the Marine Environment: A Review from Textile Perspective with a Focus on Domestic Washings. Science of the Total Environment, 598, 1116-1129. https://doi.org/10.1016/j.scitotenv.2017.04.172

[107] Jonsson, C., Arturin, O.L., Hanning, A.-C., Landin, R., Holmstrom, E. and Roos, S. (2018) Microplastics Shedding from Textiles-Developing Analytical Method for Measurement of Shed Material Representing Release during Domestic Washing. Sustainability, 10, 2457. https://doi.org/10.3390/su10072457

[108] de Falco, F., Gullo, M.P., Gentile, G., Di Pace, E., Cocca, M., Gelabert, L., Brouta-Agnesa, M., Rovira, A., Escudero, R., Villalba, R., Mossotti, R., Montarsolo, A., Gavignano, S., Tonin, C. and Avella, M. (2018) Evaluation of Microplastic Release Caused by Textile Washing Processes of Synthetic Fabrics. Environmental Pollution, 236, 916-925. https://doi.org/10.1016/j.envpol.2017.10.057

[109] Talvitie, J., Mikola, A., Setälä, O., Heinonen, M. and Koistinen, A. (2017) How Well Is Microlitter Purified from Wastewater? A Detailed Study on the Stepwise Removal of Microlitter in a Tertiary Level Wastewater Treatment Plant. Water Research, 109, 164-172. https://doi.org/10.1016/j.watres.2016.11.046

[110] Talvitie, J., Mikola, A., Koistinen, A. and Setälä, O. (2017) Solutions to Microplastic Pollution-Removal of Microplastics from Wastewater Effluent with Advanced Wastewater Treatment Technologies. Water Research, 123, 401-407. https://doi.org/10.1016/j.watres.2017.07.005

[111] Carr, S.A., Liu, J. and Tesoro, A.G. (2016) Transport and Fate of Microplastic Particles in Wastewater Treatment Plants. Water Research, 91, 174-182. https://doi.org/10.1016/j.watres.2016.01.002 
[112] Magnusson, K. and Norén, F. (2014) Screening of Microplastic Particles in and Down-Stream a Wastewater Treatment Plant. Report C55, Swedish Environmental Research Institute, Stockholm.

[113] Mahon, A.M., O’Connell, B., Healy, M.G., O'Connor, I., Officer, R., Nash, R. and Morrison, L. (2017) Microplastics in Sewage Sludge: Effects of Treatment. Environmental Science \& Technology, 51, 810-818. https://doi.org/10.1021/acs.est.6b04048

[114] Mason, S.A., Garneau, D., Sutton, R., Chu, Y., Ehmann, K., Barnes, J., Fink, P., Papazissimos, D. and Rogers, D.L. (2016) Microplastic Pollution Is Widely Detected in US Municipal Wastewater Treatment Plants Effluent. Environmental Pollution, 218, 1045-1054. https://doi.org/10.1016/j.envpol.2016.08.056

[115] Michielssen, M.R., Michielssen, E.R., Ni, J. and Duhaime, M.B. (2016) Fate of Microplastics and Other Anthropogenic Litter (SAL) in Wastewater Treatment Plants Depends on the Unit Processes Involved. Environmental Science: Water Research \& Technology, 2, 1064-1073. https://doi.org/10.1039/C6EW00207B

[116] Mintenig, S.M., Int-Veen, I., Löder M. and Gerdts, G. (2014) Mikroplastik in ausgewählten Kläranlagen des Oldenburgisch-Ostfriesischen Wasserverbandes (OOWV) in Niedersachsen. Probenanalyse mittels Mikro-FTIR Spektroskopie. [MikroPlastik in Selected Sewage Treatment Plants of the Oldenburgisch-Ostfriesischen Water Board in Niedersachsen. Sample Analysis Using microFTIR Spectroscopy] Alfred-Wegener-Institut, Helmholtz-Zentrum für Polar-und Meeresforschung (AWI), Biologische Anstalt Helgoland. (In German)

[117] Murphy, F., Ewins, C., Carbonnier, F. and Quinn, B. (2016) Wastewater Treatment Works (WwTW) as a Source of Microplastics in the Aquatic Environment. Environmental Science \& Technology, 50, 5800-5808. https://doi.org/10.1021/acs.est.5b05416

[118] Talvitie, J., Heinonen, M., Paakkonen, J.-P., Vahtera, E., Mikola, A., Setala, O. and Vahala, R. (2015) Do Wastewater Treatment Plants Act as a Potential Point Source of Microplastics? Preliminary Study in Coastal Gulf of Finland, Baltic Sea. Water Science \& Technology, 72, 1495-1504. https://doi.org/10.2166/wst.2015.360

[119] Vermaire, J.C., Pomeroy, C., Herczegh, S.M., Haggart, O. and Murphy, M. (2017) Microplastic Abundance and Distribution in the Open Water and Sediment of the Ottawa River, Canada, and Its Tributaries. Facets, 2, 301-314.

https://doi.org/10.1139/facets-2016-0070

[120] NYU-OAG (2015) New York State Office of the Attorney General, Discharging Microbeads to Our Waters: An Examination of Wastewater Treatment Plants in New York.

[121] Morritt, D., Stefanoudis, P.V., Pearce, D., Crimmen, O.A. and Clark, P.F. (2014) Plastic in the Thames: A River Runs through It. Marine Pollution Bulletin, 78, 196-200. https://doi.org/10.1016/j.marpolbul.2013.10.035

[122] Estahbanadi, S. and Fahrenfeld, N.L. (2016) Influence of Wastewater Treatment Plant Discharges on Microplastic Concentrations in Surface Water. Chemosphere, 162, 277-284. https://doi.org/10.1016/j.chemosphere.2016.07.083

[123] Kay, P., Hiscoe, R., Moberley, I., Bajic, L. and McKenna, N. (2018) Wastewater Treatment Plants as a Source of Microplastics. Environmental Science and Pollution Research, 25, 20264-20267. https://doi.org/10.1007/s11356-018-2070-7

[124] Mani, T., Hauk, A., Walter, U. and Burkhardt-Holm, P. (2015) Microplastics Profile along the Rhine River. Scientific Reports, 5, Article No. 17988.

https://doi.org/10.1038/srep17988 
[125] Eriksen, M., Mason, S., Wilson, S., Box, C., Zellers, A., Edwards, W., Farley, H. and Amato, S. (2013) Microplastic Pollution in the Surface Waters of the Laurentian Great Lakes. Marine Pollution Bulletin, 77, 177-182. https://doi.org/10.1016/j.marpolbul.2013.10.007

[126] Gallagher, A., Rees, A., Rowe, R., Stevens, J. and Wright, P. (2016) Microplastics in the Solent Estuarine Complex, UK: An Initial Assessment. Marine Pollution Bulletin, 102, 243-249. https://doi.org/10.1016/j.marpolbul.2015.04.002

[127] Mintenig, S.M., Int-Veen, I., Löder, M.G.J., Primpke, S. and Gerdts, G. (2017) Identification of Microplastic in Effluents of Waste Water Treatment Plants Using Focal Plane Array-Based Micro-Fourier-Transform Infrared Imaging. Water Research, 108, 365-372. https://doi.org/10.1016/j.watres.2016.11.015

[128] Correia Prata, J. (2018) Microplastics in Wastewater: State of Knowledge on Sources, Fate and Solutions. Marine Pollution Bulletin, 129, 262-265.

https://doi.org/10.1016/j.marpolbul.2018.02.046

[129] Castañeda, R.A., Avijas, S., Simard, M.A. and Ricciardi, A. (2014) Microplastic Pollution in St. Lawrence River Sediments. Canadian Journal of Fisheries and Aquatic Sciences, 71, 1767-1771. https://doi.org/10.1139/cjfas-2014-0281

[130] Rochman, C.M., Kross, S.M., Armstrong, J.B., Bogan, M.T., Darling, E.S., Green, S.J., Smyth, A.R. and Verissimo, D. (2015) Scientific Evidence Supports a Ban on Microbeads. Environmental Science \& Technology, 49, 10759-10761. https://doi.org/10.1021/acs.est.5b03909

[131] Fendall, L.S. and Sewell, M.A. (2009) Contributing to Marine Pollution by Washing Your Face: Microplastics in Facial Cleansers. Marine Pollution Bulletin, 58, 1225-1228. https://doi.org/10.1016/j.marpolbul.2009.04.025

[132] Unice, K.M., Weeber, M.P., Abramson, M.M., Reid, R.C.D., van Gils, J.A.G., Markus, A.A.., Vethaak, A.D. and Panko, J.M. (2019) Characterizing Export of Land-Based Microplastics to the Estuary Part 1: Application of Integrated Geospatial Microplastic Transport Models to Assess Tire and Road Wear Particles in the Seine Watershed. Science of the Total Environment, 646, 1639-1649. https://doi.org/10.1016/j.scitotenv.2018.07.368

[133] Unice, K.M., Weeber, M.P., Abramson, M.M., Reid, R.C.D., van Gils, J.A.G., Markus, A.A., Vethaak, A.D. and Panko, J.M. (2019) Characterizing Export of Land-Based Microplastics to the Estuary Part II: Sensitivity Analysis of an Integrated Geospatial Microplastic Transport Modeling Assessment of Tire and Road Wear Particles. Science of the Total Environment, 646, 1650-1659.

https://doi.org/10.1016/j.scitotenv.2018.08.301

[134] Siegfried, M., Koelmans, A.A., Besseling, E. and Kroeze, C. (2017) Export of Microplastics Form Land to Sea. A Modelling Approach. Water Research, 127, 249-257. https://doi.org/10.1016/j.watres.2017.10.011

[135] Gustavsson, M. (2001). Icke-avgasrelterade partiklar I vägmiljön, VTI meddelande 910.

[136] Li, Y., Lau, S., Kayhanian, M. and Stenstrom, M. (2005) Particle Size Distribution in Highway Runoff. Journal of Environmental Engineering, 131, 1267-1276. https://doi.org/10.1061/(ASCE)0733-9372(2005)131:9(1267)

[137] Thorpe, A. and Harrison, R.M. (2008) Sources and Properties of Non-Exhaust Particulate Matter from Road Traffic: A Review. Science of the Total Environment, 400, 270-282. https://doi.org/10.1016/j.scitotenv.2008.06.007

[138] Wagner, S., Hüffer, T., Klöckner, P., Wehrhahn, M., Hofmann, T. and Reemtsma, T. (2018) Tire Wear Particles in the Aquatic Environment: A Review on the Gener- 
ation, Analysis, Occurrence, Fate and Effects. Water Research, 139, 83-100. https://doi.org/10.1016/j.watres.2018.03.051

[139] Burns, E.E. and Boxall, A.B.A. (2018) Microplastics in the Aquatic Environment: Evidence for or against Adverse Impacts and Major Knowledge Gaps. Environmental Toxicology and Chemistry, 37, 2776-2796. https://doi.org/10.1002/etc.4268

[140] Ziajahromi, S., Neale, P.A., Rintoul, L. and Leusch, F.D.L. (2017) Wastewater Treatment Plants as a Pathway for Microplastics: Development of a New Approach to Sample Wastewater-Based Microplastics. Water Research, 112, 93-99. https://doi.org/10.1016/j.watres.2017.01.042

[141] Sutton, R., Mason, S.A., Stanek, S.K., Willis-Norton, E., Wren, I.F. and Box, C. (2016) Microplastic Contamination in the San Francisco Bay, California, USA. Marine Pollution Bulletin, 109, 230-235.

https://doi.org/10.1016/j.marpolbul.2016.05.077

[142] Vesilend, P.A. (2003) Wastewater Treatment Plant Design. Water Environment Federation, Virginia.

[143] Lares, M., Ncibi, M.C., Sillanpää, M. and Sillanpää, M. (2018) Occurrence, Identification and Removal of Microplastic Particles and Fibers in Conventional Activated Sludge Process and Advanced MBR Technology. Water Research, 133, 236-246. https://doi.org/10.1016/j.watres.2018.01.049

[144] Dyachenko, A., Mitchell, J. and Arsem, N. (2017) Extraction and Identification of Microplastic Particles from Secondary Wastewater Treatment Plant (WWTP) Effluent. Analytical Methods, 9, 1412-1418. https://doi.org/10.1039/C6AY02397E

[145] Talvitie, J. and Heinonen, M. (2014) Preliminary Study on Synthetic Microfibers and Particles at a Municipal Waste Water Treatment Plant, HELCOM BASE Project Implementation of the Baltic Sea Action Plan in Russia.

[146] Gündoğdu, S., Çevik, C., Güzel, E. and Kilercioğlu, S. (2018) Microplastics in Municipal Wastewater Treatment Plants in Turkey: A Comparison of the Influent and Secondary Effluent Concentrations. Environmental Monitoring and Assessment, 190, 626-632. https://doi.org/10.1007/s10661-018-7010-y

[147] Kalčíková, G., Alič, B., Skalar, T., Bundschuh, M. and Žgajnar Gotvajn, A. (2017) Wastewater Treatment Plant Effluents as Source of Cosmetic Microbeads to Freshwater. Chemosphere, 188, 25-31.

https://doi.org/10.1016/j.chemosphere.2017.08.131

[148] Simon, M., van Alst, N. and Vollertsen, J. (2018) Quantification of Microplastic Mass and Removal Rates at Wastewater Treatment Plants Applying Focal Plane Array (FPA)-Based Fourier Transform Infrared (FT-IR) Imaging. Water Research, 142, 1-9. https://doi.org/10.1016/j.watres.2018.05.019

[149] Gies, E.A., LeNoble, J.L., Noël, M., Etemadifar, A., Bishay, F., Hall, E.R. and Ross, P.S. (2018) Retention of Microplastics in a Major Secondary Wastewater Treatment Plant in Vancouver, Canada. Marine Pollution Bulletin, 133, 553-561. https://doi.org/10.1016/j.marpolbul.2018.06.006

[150] Wisniowska, E., Moraczewska-Majkut, K. and Nocon, W. (2018) Efficiency of Microplastics Removal in Selected Wastewater Treatment Plants: Preliminary Studies. Desalination and Water Treatment, 134, 316-323. https://doi.org/10.5004/dwt.2018.23418

[151] Yang, L., Li, K., Cui, S., Kang, Y., An, L. and Lei, K. (2019) Removal of Microplastics in Municipal Sewage from China's Largest Water Reclamation Plant. Water Research, 155, 175-181. https://doi.org/10.1016/j.watres.2019.02.046

[152] Bayo, J., Olmos, S. and Castellanos Lopez, J. (2019) Microplastics in an Urban 
Wastewater Treatment Plant: The Influence of Physicochemical Parameters and Environmental Factors. Chemosphere, 238, 124593. https://doi.org/10.1016/j.chemosphere.2019.124593

[153] Long, Z., Pan, Z., Wang, W., Ren, J., Yu, X., Lin, L., Lin, H., Chen, H. and Jin, X. (2019) Microplastic Abundance, Characteristics, and Removal in Wastewater Treatment Plants in a Coastal City of China. Water Research, 155, 255-265. https://doi.org/10.1016/j.watres.2019.02.028

[154] Blair, R.M., Waldron, S. and Gauchotte-L, C. (2019) Average Daily Flow of Microplastics through a Tertiary Wastewater Treatment Plant over a Ten-Month Period. Water Research, 163, Article ID: 114909. https://doi.org/10.1016/j.watres.2019.114909

[155] Xu, X., Jian, Y., Xue, Y., Hou, Q. and Wang, L.-P. (2019) Microplastics in the Wastewater Treatment Plants (WWTPs): Occurrence and Removal. Chemosphere, 235, 1089-1096. https://doi.org/10.1016/j.chemosphere.2019.06.197

[156] Lv, X., Dong, Q., Zuo, Z., Liu, Y., Huang, X. and Wu, W.-M. (2019) Microplastics in a Municipal Wastewater Treatment Plant: Fate, Dynamic Distribution, Removal Efficiencies, and Control Strategies. Journal of Cleaner Production, 225, 579-586. https://doi.org/10.1016/j.jclepro.2019.03.321

[157] Liu, X., Yuan, W., Di, M., Li, Z. and Wang, J. (2019) Transfer and Fate of Microplastics during the Conventional Activated Sludge Process in One Wastewater Treatment Plant of China. Chemical Engineering Journal, 362, 176-182. https://doi.org/10.1016/j.cej.2019.01.033

[158] Wolff, S., Kerpen, J., Prediger, J., Barkmann, L. and Müller, L. (2019) Determination of the Microplastics Emission in the Effluent of a Municipal Waste Water Treatment Plant Using Raman Microspectroscopy. Water Research $X$, 2, Article ID: 100014. https://doi.org/10.1016/j.wroa.2018.100014

[159] Conley, K., Clum, A., Deepe, J., Lane, H. and Beckingham, B. (2019) Wastewater Treatment Plants as a Source of Microplastics to an Urban Estuary: Removal Efficiencies and Loading per Capita over One Year. Water Research X, 3, Article ID: 100030. https://doi.org/10.1016/j.wroa.2019.100030

[160] Magni, S., Binelli, A., Pittura, L., Avio, C.G., Della Torre, C., Parenti, C.C., Gorbi, S. and Regoli, F. (2019b) The Fate of Microplastics in an Italian Wastewater Treatment Plant. Science of the Total Environment, 652, 602-610. https://doi.org/10.1016/j.scitotenv.2018.10.269

[161] Primpke, S., Imhof, H., Piehl, S., Lorenz, C., Loeder, M., Laforsch, C. and Gerdts, G. (2017) Environmental Chemistry Microplastic in the Environment. Chemie in Unserer Zeit, 51, 402-412. https://doi.org/10.1002/ciuz.201700821

[162] Cheung, P.K. and Fok, L. (2017) Characterization of Plastic Microbeads in Facial Scrubs and Their Estimated Emissions in Mainland China. Water Research, 122, 53-61. https://doi.org/10.1016/j.watres.2017.05.053

[163] Rochman, C.M., Kross, S.M., Armstrong, J.B., Bogan, M.T., Darling, E.S., Green, S.J., Smyth, A.R. and Verissimo, D. (2015) Scientific Evidence Supports a Ban on Microbeads. Environmental Science \& Technology, 49, 10759-10761. https://doi.org/10.1021/acs.est.5b03909

[164] Maupin, M.A., Kenny, J.F., Hutson, S.S., Lovelace, J.K., Barber, N.L. and Linsey, K.S. (2014) Estimated Use of Water in the United States in 2010. US Geological Survey Circular 1405. https://doi.org/10.3133/cir1405

[165] Kole, P.J., Löhr, A.J., van Belleghem, F.G.A. and Ragas, A.M.J. (2017) Wear and Tear of Tyres: A Stealthy Source of Microplastics in the Environment. International 
Journal of Environmental Research and Public Health, 14, E1265-E1265. https://doi.org/10.3390/ijerph14101265

[166] Vollertsen, J. and Hansen, A.A. (2017) Microplastic in Danish Wastewater: Sources, Occurrences and Fate. Environmental Project Vol. 1906, Danish Environmental Protection Agency, 55.

[167] Kreidler, M.L., Panko, J.M., McAtee, B.L., Sweet, L.I. and Finley, B.L. (2010) Physical and Chemical Characterization of Tire-Related Particles: Comparison of Particles Generated Using Different Methodologies. Science of the Total Environment, 408, 652-659. https://doi.org/10.1016/j.scitotenv.2009.10.016

[168] Brandsma, S.H., Nijssen, P., van Velzen M.J.M. and Leslie, H.A. (2013) Microplastics in River Suspended Particulate Matter and Sewage Treatment Plants. Report R14/02, Version 1, IVM Institute for Environmental Studies, Amsterdam.

[169] Habib, D., Locke, D.C. and Cannone, L.J. (1998) Synthetic Fibers as Indicators of Municipal Sewage Sludge, Sludge Products and Sewage Treatment Plant Effluents. Water, Air, \& Soil Pollution, 103, 1-8. https://doi.org/10.1023/A:1004908110793

[170] Lusher, A.L., Hurley, R., Vogelsang, C., Nizzetto, L. and Olsen, M. (2018) Mapping Microplastics in Sludge. Technical Report L.NR. 7215-2017 (NIVA).

[171] Sujathan, S., Kniggendorf, A.-K., Kumar, A., Roth, B., Rosenwinkel, K.H. and Nogueira, R. (2017) Heat and Bleach: A Cost-Efficient Method for Extracting Microplastics from Return Activated Sludge. Archives of Environmental Contamination and Toxicology, 73, 641-648. https://doi.org/10.1007/s00244-017-0415-8

[172] Zhou, Q., Tian, C. and Luo, Y. (2017) Various Forms and Deposition Fluxes of Microplastics Identified in the Coastal Urban Atmosphere. Chinese Science Bulletin, 62, 3902-3909. https://doi.org/10.1360/N972017-00956

[173] He, D., Luo, Y., Lu, S., Liu, M., Song, Y. and Lei, L. (2018) Microplastics in Soils: Analytical Methods, Pollution Characteristics and Ecological Risks. Trends in Analytical Chemistry, 109, 163-172. https://doi.org/10.1016/j.trac.2018.10.006

[174] Hurley, R.R. and Nizzetto, L. (2018) Fate and Occurrence of Micro(nano)plastics in Soils: Knowledge Gaps and Possible Risks. Current Opinion in Environmental Science \& Health, 1, 6-11. https://doi.org/10.1016/j.coesh.2017.10.006

[175] Bläsing, M. and Amelung, W. (2018) Plastics in Soil: Analytical Methods and Possible Sources. Science of the Total Environment, 612, 422-435. https://doi.org/10.1016/j.scitotenv.2017.08.086

[176] de Souza Machado A.A., Kloas, W., Zarfl, C., Hempel, S. and Rillig, M.C. (2018) Microplastics as an Emerging Threat to Terrestrial Ecosystems. Global Change Biology, 24, 1405-1416. https://doi.org/10.1111/gcb.14020

[177] Li, X.W., Chen, L.B., Mei, Q.Q., Dong, B., Dai, X.H., Ding, G.J. and Zeng, E.Y. (2018) Microplastics in Sewage Sludge from the Wastewater Treatment Plants in China. Water Research, 142, 75-85. https://doi.org/10.1016/j.watres.2018.05.034

[178] Nizzetto, L., Futter, M. and Langaas, S. (2016) Are Agricultural Soils Dumps for Microplastics of Urban Origin? Environmental Science \& Technology, 50, 10777-10779. https://doi.org/10.1021/acs.est.6b04140

[179] Ali, M.I., Ahmed, S., Robson, G., Javed, I., Ali, N., Atiq, N. and Hameed, A. (2014) Isolation and Molecular Characterization of Polyvinyl Chloride (PVC) Plastic Degrading Fungal Isolates. Journal of Basic Microbiology, 54, 18-27. https://doi.org/10.1002/jobm.201200496

[180] Habib, R.Z., Abdoon, S.M.M., Meqbaali, R.M., Ghebremedhin, F., Elkashlan, M., Kittaneh, W.F., Cherupurakal, N., Mourad, A.I., Thiemann, T. and Al Kindi, R. 
(2020) Analysis of Cosmetic products Available in United Arab Emirates. Environmental Pollution, 258, Article ID: 113831.

https://doi.org/10.1016/j.envpol.2019.113831

[181] Rom, M., Fabia, J., Grubel, K., Sarna, E., Graczyk, T. and Janicki, J. (2017) Study of the Biodegradability of Polylactide Fibers in Wastewater Treatment Processes. Polimery, 62, 834-840. https://doi.org/10.14314/polimery.2017.834

[182] Badore, M. (2013) 3 Companies Commit to Removing Plastic Beads from Their Body Products. Treehugger, 2nd July.

http://www.treehugger.com/clean-water/3-companies-commit-removing-plastic-be ads-their-body-products.html

[183] Barlas, T. (2015) Campaign to Rid Australian Waterways of Microbeads Wins Backing of Clarins, Clearasil and Ella Baché Sydney Morning Herald.

[184] United Nations Environment Programme (UNEP) Plastic Cosmetics (2015) Are We Polluting the Environment through Our Personal Care? http://unep.org/gpa/documents/publications/PlasticinCosmetics2015Factsheet.pdf

[185] Mourshed, M., Masud, M., Rashid, F. and Joarddeer, M.U.H. (2017) Towards Effective Plastic Waste Management in Bangladesh: A Review. Environmental Science and Pollution Research, 24, 27021-27046.

https://doi.org/10.1007/s11356-017-0429-9

[186] Wilkinson, J., Hooda, P.S., Barker, J., Barton, S. and Swinden, J. (2017) Occurrence, Fate and Transformation of Emerging Contaminants in Water: An Overarching Review of the Field. Environmental Pollution, 231, 954-970.

https://doi.org/10.1016/j.envpol.2017.08.032

[187] DEFRA (2017) Microbead Ban Announced to Protect Sealife [Online]. https://www.gov.uk/government/news/microbead-ban-announced-to-protect-sealif e

[188] National Law Information Center (2017) Regulations on Safety Standards for Cosmetics (South Korea).

https://chemicalwatch.com/asiahub/74677/south-korea-in-research-phase-of-broad er-microplastics-regulation

[189] Imhof, H.K., Sigl, R., Brauer, E., Feyl, S., Giesemann, P., Klink, S., Leupolz, K., Löder, M.G.J., Löschel, L.A., Missun, J., Muszynski, S., Ramsperger, A.F., Schrank, I., Speck, S., Steinl, S., Trotter, B., Witner, I. and Laforsch, C. (2017) Spatial and Temporal Variation of Macro-, Meso- and Microplastic Abundance on a Remote Coral Island of the Maldives, Indian Ocean. Marine Pollution Bulletin, 116, 340-347. https://doi.org/10.1016/j.marpolbul.2017.01.010

[190] Nel, H.A., Hean, J.W., Noundou, X.S. and Froneman, P.W. (2017) Do Microplastic Loads Reflect the Population Demographics along the Southern African Coastline. Marine Pollution Bulletin, 115, 115-119. https://doi.org/10.1016/j.marpolbul.2016.11.056

[191] Pivonkovsky, M., Cermakova, L., Novotna, K., Peer, P., Cajthami, T. and Janda, V. (2018) Occurrence of Microplastics in Raw and Treated Drinking Water. Science of the Total Environment, 643, 1644-1651.

https://doi.org/10.1016/j.scitotenv.2018.08.102

[192] Oßmann, B.E., Sarau, G., Holtmannspötter, H., Pitschetsrieder, M., Christiansen, S.H. and Dicke, W. (2018) Small-Sized Microplastics and Pigmented Particles in Bottled Mineral Water. Water Research, 141, 307-316. https://doi.org/10.1016/j.watres.2018.05.027

[193] Liebezeit, G. and Liebezeit, E. (2013) Non-Pollen Particulates in Honey and Sugar, 
Food Additives \& Contaminants. Part A: Chemistry, Analysis, Control, Exposure \& Risk Assessment, 30, 2136-2140. https://doi.org/10.1080/19440049.2013.843025

[194] Liebezeit, G. and Liebezeit, E. (2014) Synthetic Particles as Contaminants in German Beers. Food Additives \& Contaminants. Part A: Chemistry, Analysis, Control, Exposure \& Risk Assessment, 31, 1574-1578.

https://doi.org/10.1080/19440049.2014.945099

[195] Karami, A., Golieskardi, A., Choo, C.K., Larat, V., Galloway, T.S. and Salamantinia, B. (2017) The Presence of Microplastics in Commercial Salts from Different Countries. Scientific Reports, 7, Article No. 46173. https://doi.org/10.1038/srep46173 